\title{
Hubert Kuberski
}

Warszawa

\section{Wschodnioeuropejscy ochotnicy cudzoziemscy w niemieckich oddziałach Ostheer, SS i policji pacyfikujących Powstanie Warszawskie. Casus „własowców”, Kałmuków i SS Galizien...*}

Historię działań wojskowych podczas Powstania Warszawskiego współtworzą fakty oraz niejednokrotnie mity. Od dziesięcioleci wykreowane legendy pokutują w świadomości ludzkiej oraz częściej w opracowaniach, a nawet monografiach naukowych. Coraz trudniej jest wykorzenić te życzeniowe wyobrażenia. W zbiorowej świadomości funkcjonują informacje o masowym wykorzystaniu przeciw powstańcom ciężkich czołgów Pz.Kpfw. VI „Tiger I” Ausf. E. Podobny charakter mają rewelacje o oddziałach „własowców”, Kałmuków i Ukraińców z tzw. SS Galizien, walczących u boku Niemców w stolicy.

\section{Początki mitu}

Obarczanie Kałmuków, Ukraińców czy „własowców” odpowiedzialnością za mordy na ludności cywilnej ma swe źródła w powstańczej propagandzie i londyńskich gazetach obozu niepodległościowego. To prasa AK upowszechniała informacje o przerzuceniu do stolicy i bestialskich sposobach walki ukraińskich oddziałów SS-Galizien oraz byłych sowieckich żołnierzy w mundurach feldgrau. Wówczas mało kto znał akronimy ROA i RONA ${ }^{1}$.

\footnotetext{
*Wcześniej artykuł, oparty jedynie na małej części,,mikrofilmów aleksandryjskich” wykorzystanych obecnie, został opublikowany jako tekst popularnonaukowy: J. Gdański, H. Kuberski, Legenda o wtasowcach, w: Pamięć Powstania '44 z przewodnikiem po Muzeum Powstania Warszawskiego, Warszawa: „Rzeczpospolita” dla MPW, 2005, s. 67; oraz H. Kuberski, J. Gdański, Uporczywa legenda: ,Własowcy” w Powstaniu Warszawskim, w: http://www.historia.gildia.pl/wiek-xx/wojskowosc/ii-wojna-swiatowa/wlasowcy-w-powstaniu-warszawskim [dostęp: 1 V 2015].

${ }^{1}$ Rosyjska Armia Wyzwoleńcza - ROA (Русская освободительная армия - POA) i Rosyjska Wyzwoleńcza Armia Ludowa - RONA (Русская освободительная народная армия — POHA). Tymczasem powstańcza prasa rozpisywała się o Ukraińcach czy Kałmukach, zob.: „Warszawa walczy” (pismo wydawane przez batalion AK „Zośka”), 2 VIII 1944, b. nr. (o „kompanii kałmyckiej” [sic!] czy też o „zezowatych pomocnikach [Niemców]”); „Biuletyn Informacyjny”, nr 41-248, Dodatek Nadzwyczajny, nr 4, 4 VIII 1944 (o Ukraińcach jako „mordercach bezbronnych” oraz ich ataku na Marszałkow-
} 
Niestety, podobne stereotypy utrzymywały się również na uchodźstwie, gdzie to Ukraińcy mieli stanowić większość strzelających z dachów do Polaków. Była to pierwsza wzmianka w gazecie wydawanej w Londynie na ich temat, gdy zwalczali Powstanie Warszawskie. „Okazało się, że znaczna liczba spośród tych strzelców, których udało się nam schwytać, to Ukraińcy. Uzbrojeni są oni przeważnie w ręczny karabin maszynowy i posiadają duży zapas amunicji [sic!]”. Później doszły jeszcze dezinformacje o udziale Kałmuków i Ukraińców w walkach przeciw Polakom. W pierwszym wypadku redaktor, opierając się na doniesieniach ze powstańczej stolicy, napisał, że „w Warszawie walczą «Kałmucy» (jeńcy rosyjscy, walczący po stronie niemieckiej)[sic!]”. W drugim wypadku, sytuacja wojskowa” została poprawniej opisana: „W szeregach niemieckich walczą Rosjanie, byli żołnierze sowieccy, którzy dziś ochotniczo walczą w WARSZAWIE po stronie Niemców”. Dzień później zostali rozpoznani jeszcze Kozacy, służący w kordonie blokującym powstańczą stolicę: „W rejonie na północ od Żoliborza zauważono patrole kawalerii kozackiej, pozostającej na usługach armii niemieckiej”. Ale z drugiej strony kilka wersów niżej pojawiła się błędna informacja o RONA: „Na Ochocie [moc] oddziałów nieprzyjacielskich, złożonych z Ukraińców. Większa część domów została spalona”. Polscy dziennikarze w Londynie za jednym z komunikatów gen. „Bora” jeszcze we wrześniu pisali: „Stwierdzono w tym rejonie [na północ i północny zachód od Marymontu, Bielany, Centralny Instytut Wychowania Fizycznego oraz Wawrzyszew] obecność oddziałów ukraińskich [sic! — Kozacy lub pułk RONA] i węgierskich, które zluzowały oddziały niemieckie"2. Jednak najszerszą informację o oddziałach w niemieckiej służbie londyńska gazeta opublikowała 12 IX 1944 r., gdy informowała za niemiecką agencją DNB o „oddziałach kaukaskich”“3.Tak powtarzane wia-

skiej). AK wydała 11 sierpnia ulotkę Ukraińcy i Azjaci - ochotnicy niemieckiej armii, którą przedrukował dwanaście dni później „Warszawski Głos Narodowy”. Jednak wcześniejsze ,rewelacje” przebił „Biuletyn Informacyjny” nr 58 z 20 VIII 1944 r., który nazwał Ukraińców „,najdzikszym narzędziem nieprzyjacielskiego terroru w Warszawie [...] Podobno sprowadzono do Warszawy oddziały osławionej dywizji SS «Hałyczyna». [...] Ale najstraszniejszym jest, że ponoszą straszliwą klęskę moralną, z której nieprędko zdołają się podnieść. Że między swym narodem, a narodem polskim wykopali nową przepaść, która dziś wydaje się przepaścią nieprzebytą z nienawiści i krwi”. Zob.: T. Bór-Komorowski, Armia podziemna, Warszawa 1988, s. 302; A. Kunert, Rzeczpospolita Walczaca. Powstanie Warszawskie, Warszawa 1994, s. 95; Powstanie Warszawskie 1944 w dokumentach z archiwów służb specjalnych, red. P. Mierecki, W. Christoforow, Warszawa-Moskwa 2007, aneks, dok. 1, s. 1071 (przekład na rosyjski autorstwa lejtnanta Wilgockiego ze SMIERSZ artykułu z powstańczej „Rzeczpospolitej Polskiej”, nr 29/101, 18 VIII 1944).

2 „Dziennik Polski i Dziennik Żołnierza” (The Polish Daily \& Soldier’s Daily), r. 1, nr 195, Londyn, piątek, 18 VIII 1944, (18. Dzień krwawi się Stolica), s. 1. Niemcy nie wykorzystywali w opisywany sposób tego typu zespołowej broni strzeleckiej, którym były wówczas rkm MG-34 i MG-42 oraz zdobyczne sowieckie DP wz. 27 - praktykowali dwuosobową obsługę rkm-u przez celowniczego i amunicyjnego, wspierających swoich kolegów na bezpośrednim przedpolu); nr 199, środa 23 VIII 1944, (Ciężkie walki o Stare Miasto), s. 1 - „Kałmucy” to faktycznie żołnierze Ostmuselmanische SS-Regiment, podporządkowani Angriffsgruppe Dirlewanger; nr 200, czwartek, 24 VIII 1944, Stare Miasto leży w gruzach, s. 1; nr 204, wtorek, 29 VIII 1944, 4 tydzień krwawi się samotnie Warszawa, s. 1 - mowa o Rosjanach z oddziału RONA i Ostbataillonen; nr 205, środa, 30 VIII 1944, Warszawa rozgoryczona na Aliantów. Niemcy zabijaja jeńców - pląruja miasto. Najcięższe ataki na Stare Miasto, s. 1; nr 215, poniedziałek, 11 IX 1944, 42 dni Warszawa walczy samotnie, s. 1; nr 221, poniedziałek, 18 IX 1944, Armia Krajowa odzyskuje inicjatywę, s. 1.

${ }^{3}$ Fragment czołówki numeru zatytułowanej Łotr pierwszej klasy zawiera najwięcej informacji o oddziałach nieniemieckich walczących przeciwko powstańcom. Oczywiście w Warszawie nie znalazły się żadne gruzińskie Ostbataillonen. Zacytujemy tekst w całości: „«Deutsche Nachrichten Büro» 
domości trafiały do pamięci czytelników, utrwalając „wiedzę” o udziale byłych obywateli RP i ZSRS w walce $\mathrm{z}$ warszawskimi powstańcami.

Po wojnie wspomniane mity były rozpowszechniane przez propagandę sowiecką, która 2 VIII 1946 r. wydała na cały świat komunikat: „W [ostatnich] dniach Kolegium Wojskowe Sądu Najwyższego ZSSR rozpatrzyło akt oskarżenia wobec Własowa A. A., Małyszkina W. F., Żylenkowa G. N., Truchina F. I., Zakutnego D. E., Błagowieszczenskiego I. A., Mieandrowa M. A., Malcewa W. I., Buniaczenki S. K., Zwierjewa G. A., Korbukowa W. D., Szatowa N. S. zdrady Ojczyzny i za to, że byli agentami wywiadu niemieckiego, prowadzili aktywną szpiegowsko-dywersyjną i terrorystyczną działalność przeciwko Związkowi Sowieckiemu, tj. przestępstw określonych $\mathrm{w}$ art. art. $58-1 \ll \mathrm{B} »^{4}, 58-8^{5}, 58-9^{6}, 58-10^{7}$ i $58-11^{8}$ Kodeksu karnego RFSRS ${ }^{9}$. Wszyscy oskarżeni przyznali się do winy w przedsta-

ogłosiło wieczorem dnia 6 września przez radio, że wybitny udział w walkach w Warszawie biorą różne «ochotnicze» oddziały. W zaciętych walkach na ulicach, kiedy trzeba zdobywać dom po domu, specjalnie odznaczyły się oddziały, złożone z Gruzinów i innych mieszkańców północnego Kaukazu [chodzi najprawdopodobniej o I/111 batalion azerski lub złożony też z Azerów II (kaukaski) batalion oddziału specjalnego „Bergmann”]. Wielu z nich zostało odznaczonych Krzyżem Żelaznym, a jeden Gruzin otrzymał za wybitne zasługi aż Krzyż Żelazny pierwszej klasy. Jest to pierwsze, tak wysokie odznaczenie, jeśli chodzi o oddziały kaukaskie. Tyle D.N.B. Oczywiście nie wolno nam oskarżać za zachowanie się najemnych band nazistowskich [Ostbataillonen nie były bandami, a regularnymi oddziałami wojskowymi — przyp. aut.], tych narodów kaukaskich, wśród których zwerbowani zostali «bohaterowie» palenia Warszawy i chowania się przed ogniem źle uzbrojonych powstańców za żywe osłony z polskich dzieci, kobiet i starców — ale w każdym razie jest to jeszcze jedna bolesna wiadomość nadchodząca z samotnie walczącej stolicy”. Zob. Okrucieństwa Niemców w Warszawie. Łotr pierwszej klasy, „Dziennik Polski i Dziennik Żołnierza”, r. 1, nr 216, wtorek, 11 IX 1944, s. 1.

${ }^{4}$ Art. $58 \S 1$ b. Zdrada ze strony personelu wojskowego: kara śmierci przez rozstrzelanie wraz z konfiskatą mienia.

${ }^{5}$ Art. 58§8. Przygotowywanie aktów terrorystycznych przeciwko przedstawicielom władzy sowieckiej i działaczom rewolucyjnych organizacji robotniczych i chłopskich: kara analogiczna do art. 58 $\S 2$ (rozstrzelanie lub ogłoszenie wrogiem robotników [ludu] wraz z konfiskatą mienia i pozbawieniem obywatelstwa republiki związkowej, a tym samym obywatelstwa ZSRS oraz wydaleniem z granic ZSRS na zawsze, przy założeniu, zgodnym z okolicznościami łagodzącymi, możliwość zmniejszenia kary pozbawienia wolności na czas nie krótszy niż trzy lata wraz z konfiskatą mienia w całości lub części.

${ }^{6}$ Art. 58 §9. Przyczynienie się do uszkodzenie systemu transportowego, zaopatrzenia w wodę, łączności oraz innych obiektów lub mienia państwowego i publicznego w celach kontrrewolucyjnych: kara analogiczna do art. $58 \S 2$.

${ }^{7}$ Art. $58 \S 10$. Propaganda lub agitacja, zawierające wezwanie do obalenia lub osłabienia władzy sowieckiej lub popełnienia innych przestępstw kontrrewolucyjnych (art. $58 \S 2$ - art. 58 §9), a także dystrybucja lub wytwarzanie lub posiadanie literatury tej samej treści niesie za sobą pozbawienie wolności na okres nie krótszy niż sześć miesięcy. Te same działania podczas masowych niepokojów lub z wykorzystaniem uprzedzeń religijnych lub nacjonalistycznych, lub w środowiskach wojskowych, lub na obszarach stosowania stanu wojennego: kara analogiczna do art. 58 §.

${ }^{8}$ Art. $58 \S 11$. Wszystkie rodzaje działań organizacyjnych skierowanych w celu przygotowania lub przewidzianych do popełnienia przestępstw w ramach niniejszego rozdziału zostają zrównane z popełnieniem takowych i zagrożone karą na mocy odpowiednich artykułów KK.

${ }^{9}$ Artykuł 58 Kodeksu karnego RFSRS (Статья 58 в Уголовном кодексе РСФСР) z 1922 r. wszedł w życie 25 II 1927 r. Stosowano go do zwalczania i pozbawiania wolności wszystkich podejrzanych o „działalność kontrrewolucyjną”. Był wielokrotnie zmieniany. W szczególności rejestr zarzutów zawartych w art. 58 § 1 został zaktualizowany i wszedł w życie 8 VI 1934 r. ze zmianami z 1 VII 1938 r., 
wionych im zarzutach. Zgodnie z artykułem 1 Dekretu Prezydium Najwyższego Sowietu ZSRS z 19 sierpnia 1943 roku Kolegium Wojskowe Sądu Najwyższego ZSSR skazało na śmierć Własowa, Małyszkina, Żylenkowa, Truchina, Zakutnego, Błagowieszczenskiego, Mieandrowa, Malcewa, Buniaczenkę, Zwierjewa, Korbukowa i Szatowa. Wyrok został wykonany [1 VIII 1946]”. Notatkę o kaźni przywódców Komitetu Wyzwolenia Narodów Rosji — KONR (Комитет Освобождения Народов России - KOHP) poprzedziły podobne wieści o skazaniu członków rządu Protektoratu Czech i Moraw oraz premiera niepodległej Słowacji Vojtecha Tuki ${ }^{10}$.

Już następnego dnia sobotni „Głosu Ludu”, gazeta Polskiej Partii Robotniczej, opublikował adekwatnie krótki do sowieckiego komunikat Własow zawisł na szubienicy. Stuszna kara spotkała zdrajce i mordercę. Tym razem pepeerowscy propagandziści zapewnili gen. Własowowi pośrednie sąsiedztwo w jednym numerze ze „zbrodniczymi emisariuszami gen. Andersa”, „szpiegami-członkami OP/NSZ”, Awanturnictwem i bankructwem. Manowcami PSL, Wyrokiem w procesie b. ministrów ,protektoratu”, natomiast bezpośrednio z demaskatorską notą Rząd angielski popiera terror $w$ Grecji $i^{11}$. W podobnym tonie skromną, lecz fałszywą wiedzę o nieznanym polskiemu społeczeństwu gen. Własowie utrwalała „Polska Zbrojna” wydawana przez Główny Zarząd Polityczno-Wychowawczy Wojska Polskiego. Lakoniczną treść, zgodną z komunikatem sowieckim, redaktor opatrzył tytułem Kaci Warszawy zawiśli na szubienicy. Co ciekawe, notka o Własowie znalazła się obok tekstu o podobnej objętości tysiąca znaków opisującym rozprawienie się z ,tajną niemiecką organizacją” przez Wojskowy Sąd Rejonowy we Wrocławiu: Wyrok w procesie członków „, Freies Deutschland”,12.

po doświadczeniach „akcji polskiej NKWD” i „Wielkiego Terroru”. Artykuł wprowadzał również oficjalnie złowieszcze pojęcie „wroga ludu”. KK innych republik sowieckich wprowadziły podobne artykuły. Przykładowo w Ukraińskiej SRS był to art. 54 tamtejszej legislacji. Zgodnie z art 58 i ich odpowiednikami prawa karnego składowych republik ZSRS zostało skazanych od 1921 do 1953 ogółem 3,78 mln w większości niewinnych osób. Zob. Уголовный кодекс РСФСР. С изменениями на 1 июля 1938 2. (Москва: Юридическое издательство Наркомюст СССР, 1938), s. 27-32.

${ }^{10}$ Wyrok skazujący wydało kolegium w składzie: generał pułkownik sprawiedliwości Wasilij Ulrich (przewodniczący sądu) oraz członkowie: generał major sprawiedliwości Fiodor Karawajkow i pułkownik sprawiedliwości G. Daniłow. Zob. Сообщение Военной Коллегии Верховного Суда Союза ССР, „Правда”, nr 182 (10264), piątek, 2 VIII 1946, s. 4 (notatka identycznej treści, objętości i miejscu Сообщение Военной Коллегии Верховного Суда Союза ССР na ostatniej kolumnie w: „Известия”, nr 181 \{9097), piątek, 2 VIII 1946, s. 4); oraz Н. Коняев, Власов. Два лица генерала (Москва: Вече, 2003), w: http://militera.lib.ru/bio/konyaev_nm/07.html [dostęp: 20 III 2014].

${ }^{11}$ Wtasow zawist na szubienicy. Stuszna kara spotkała zdrajcę i morderce, „Głos Ludu”, nr 211 (599), 3 VIII 1946, s. 5. Zob. BN, Mf. 40821.

${ }^{12}$ Wiosną 1945 r. miała powstać organizacja podziemna „Wolne Niemcy” (Freies Deutschland - FD), której nazwę można uznać za wymysł UB. Podlegali jej dowódcy okręgów (Gau) które pokrywały się z granicami województw. W Polsce siedziba jednego z okręgów mieściła się we Wrocławiu. Dowódcą miał być gen. Balzer (lub Balteser — mógłby to być Generalmajor Richard Baltzer — dowódca 182 Infanterie-Division - ale on kapitulował 10 V 1945 r. w imieniu Wehrmachtu w Pradze). Organizacja ta na terenach podległych administracji polskiej liczyła przypuszczalnie około 1400 członków. Najaktywniej działała w powiecie bolesławieckim, gdzie na jej czele stał inżynier — b. kapitan Luftwaffe - Artur Kühne, najważniejszy skazany. Freies Deutschland istniała w Jeleniej Górze, Lwówku Śląskim, Miliczu, Legnicy, Zgorzelcu i Lubaniu, nie prowadząc czynnej działalności poza organizacyjną, werbunkową i wywiadowczą. W 1946 r. funkcjonariusze MO i UB we współdziałaniu z KBW i lWP częściowo rozbili najaktywniejszą organizację w powiecie bolesławieckim oraz kilka innych komórek organizacji FD. Ogółem na Śląsku rozbito cztery komórki organizacyjne. Większość jej członków wyjechała z Polski za Odrę transportami wysiedleńczymi wraz z wysiedlaną ludnością niemiecką. Zob. In- 
To mogło utwierdzać czytelników w przekonaniu, że Własow był nie tylko zły, ale i zdradziecki ${ }^{13}$.

Podobny dezinformujący charakter miał niewielki artykuł pod tytułem Generał Własow $i$ wspólnicy zawiśli na szubienicy w Moskwie w „Gazecie Ludowej”. PSL-owski dziennik informował też w sobotnim wydaniu swej gazety o skazaniu na śmierć generała Nikolausa von Falkenhorsta, ,jednej kobiecie i pięciu wojskowych [w] procesie o szpiegostwo OP i NSZ". Ponadto znalazło się miejsce dla dużego tekstu wspomnieniowego o okupacyjnym znaczeniu SL w Polskim Państwie Podziemnym autorstwa Stefana Korbońskiego Rola „,Trójkąta” w Polsce Podziemnej oraz apelu o to, że „Niemcy muszą pokryć koszty odbudowy Warszawy" "14. Jednak tym, co łączyło trzy redakcje, był cytowany komunikat PAP kończący się stwierdzeniem: „Andrej Andrejewicz Własow, dawny generał w służbie radzieckiej, zdradził swą ojczyznę i utworzył «legion rosyjski» w służbie Niemiec. Oddziały Własowa były chętnie używane przez Niemców do najbardziej okrutnej akcji policyjnej na terytorium Polski m.in. w Warszawie”. Wyraźnie widoczny nadzór Głównego Urzędu Kontroli Prasy, Publikacji i Widowisk (GUKPPiW) sygnalizował, że oficjalna prasa w Polsce w latach czterdziestych XX w. przemawiała jednym głosem.

Więcej informacji zawierała kilkuzdaniowa notka Gen. Własow powieszony w „Dzienniku Polski i Dzienniku Żołnierza”. Autor informował, że „Gen. Własow, twórca słynnego korpusu antysowieckiego [dwóch dywizji grenadierów WS KONR — przyp. aut.], utworzonego z jeńców rosyjskich [sowieckich] w Niemczech, został skazany na śmierć przez trybunał sowiecki. O procesie Własowa ogłoszono w Moskwie komunikat, dopiero po wykonaniu wyroku. Proces odbył się w całkowitej tajemnicy. Widocznie władze sowieckie nie życzyły sobie, by z okazji procesu wyszły na jaw szczegóły masowej zdrady w szeregach Czerwonej Armii i popularności akcji podjętej przez Własowa". Te informacje nie miały jak przeniknąć za żelazną kutynę ${ }^{15}$.

Krajowe rewelacje szybko się zakorzeniły za sprawą prasy, opracowań i wspomnień. Już wydana rok po wojnie w Poznaniu książka Edwarda Serwańskiego i Ireny Trawińskiej była zdominowana przez „Ukraińców” uzupełnionych o „Kałmuków” i „Mongołów” (oraz „Tygrysy”). Podobne uproszczenia zawierało przesłuchanie szefa Oddziału IV Komendy Głównej AK, ppłk. dypl. Augustyna Walusia, przez oficera Smiersz potwierdzające słabą orientację nawet wyższej kadry oficerskiej, z kim walczyła AK: „W dzielnicach mias[ta] Warszawy — Stare Miasto, Mokotów i Żoliborz od pierwszych dni brały udział w thumieniu powstania jednostki piechoty i czołgów armii niemieckiej (numerów tych formacji nie znam), w szczególności, jak później słyszałem, była to dywizja pancerna SS «Wiking» [sic! Tylko 3 bateria pułku artylerii przeciwlotniczej SS «Wiking» oraz zdobyty zabłąkany półgąsienicowy transporter opancerzony Sd.Kfz. 251/1 Ausf. D należący do 5 pancernego batalionu łączności SS-Pz. Div. 5. «Wiking» — SS-Panzer-Nachrichtenabteilung 5]. Natomiast $\mathrm{w}$ pozostałych dzielnicach $\mathrm{w}$ thumieniu powstania uczestniczyła żandarmeria i oddziały sformowane przez Niemców z sowieckich jeńców wojennych («Legion

formator o nielegalnych antypaństwowych organizacjach $i$ bandach zbrojnych działajacych $w$ Polsce Ludowej w latach 1944-1956, Warszawa - 1964 rok (Lublin 1993), s. 157, 158; Z. Szczepański, Pohitlerowskie podziemie w Bolesławcu, „Rocznik Jeleniogórski”, t. XXIII, Wrocław 1985, s. 86-95.

${ }^{13}$ Kaci Warszawy zawiśli na szubienicy, „Polska Zbrojna”, nr 183 (467), 3 VIII 1946, s. 5. Zob. BN, Mf. 55059.

${ }_{14}$ Generat Własow i wspólnicy zawiśli na szubienicy w Moskwie, „Gazeta Ludowa”, r. 2, nr 211, 3 VIII 1946, s. 1. Zob. BN, Mf. 45132.

15 „Dziennik Polski i Dziennik Żołnierza”, r. 3, nr 181, Londyn, sobota, 3 VIII 1946, s. 1. 
Wschodni» [Ostlegionen], ukraińska dywizja SS «Galizien» [sic!] i oddziały tak zwanej «ROA» [pomyłka z RONA])"16.

Odpowiedzialność za upowszechnianie mitów w Londynie ponosi opublikowana w tym samym roku „specjalistyczna” rozprawa Andrzeja Pomiana-Dowmuntta. Praca „została napisana jako wstęp do obszernego wyboru źródeł z okresu Powstania Warszawskiego", rojąc się od licznych przeinaczeń. Podobnie mylił się Antoni Chruściel ps. „Monter” w swoim powojennym opracowaniu napisanym w Londynie. Legendę ,własowców” powielały też dwie polskie monografie Powstania Warszawskiego. Kirchmayer i Borkiewicz błędnie rozwodzili się o ,żołnierzach wschodnich” (Osttruppen), stacjonujących i walczących w Warszawie, myląc oddziały, a wszystko, co wschodnie, utożsamiając z własowskim, ukraińskim lub kałmuckim skrótem myślowym. Opinia publiczna podchwyciła poglądy peerelowskich publikacji. Najczęstszym błędem stało się mylenie ROA z RONA, co faktycznie utrwaliło mit o walkach „własowców”, Ukraińców i „Kałmuków” z powstańcami. Lata zaniedbań w badaniach niemieckich archiwaliów dają o sobie znać nieustannie ${ }^{17}$.

\section{Faktycznie odpowiedzialni}

Niemcy spodziewali się wybuchu powstania w Warszawie, gdyż od czerwca 1944 r. obowiązywał w Generalnym Gubernatorstwie trzystopniowy plan alarmowy. W jego ramach pierwsze dwa stopnie zakładały stan alarmu dla policji, SS oraz paramilitarnych organizacji (Bahnschutz, Werkschutz, SA itd.). Dopiero przy trzecim stopniu Niemcy uwzględniali użycie jednostek Wehrmachtu, a zwalczanie powstania miało zostać podporządkowane wojskowemu komendantowi garnizonu Warszawa Generalleutnantowi Rainerowi Stahelowi: „W przeddzień, 31 lipca, wezwałem do siebie wszystkich komendantów dzielnic Warszawy, którzy mieli już w rękach podobne plany działania na wypadek powstania, i uprzedziłem ich o maksymalnej czujności, gdyż w każdej chwili należy liczyć się z rozpoczęciem powstania. Pierwszego sierpnia informowałem gubernatora, dowodzącego 9 Armią, i komendantów sektorów, że dziś spodziewane jest wystąpienie Polaków. Tego samego wieczora ogłosiłem w mieście stan oblężenia”.

${ }^{16}$ Powstanie Warszawskie $1944 w$ dokumentach z archiwów stużb specjalnych, red. P. Mierecki, W. Christoforow (dalej: Powstanie...), Warszawa-Moskwa 2007, dok. 97 (Protokół przesłuchania ppłk. dypl. Augustyna Walusia [przez ppłk BP [GB] Czernycha ze Smiersz, Warszawa], 21 III 1945), s. 564; Zbrodnia niemiecka $w$ Warszawie 1944 r.: zeznania-zdjęcia, „Documenta Occupationis Teutonicae”, t. II, opr. E. Serwański, I. Trawińska, Poznań 1946, s. 24, 133, 155, 172 („Kałmucy”), 65 („Mongoł”), 41, 43, 45, 68, 157, 189 („Tygrysy”), 33-37, 42-46, 51, 62, 66, 71, 80, 81, 86-94, 96-119, 132, 135, $148,155,160-162,170,177-179,183-186,196$ („Ukraińcy” — widać z tego prawdopodobny zamiar redakcyjny określania nadużywanym mianem wszystkich ochotników wschodnioeuropejskich Ostheer, w tym RONA.

${ }^{17}$ W kolejności chronologicznej: R. Goldman, Bój Warszawy 1 sierpień-2 październik 1944, b.m.w. 1945; Powstanie Warszawskie. Antologia tekstów nieobecnych (dalej: Antologia... nieobecnych, red. Z. J. Sawicki, Torun 2004, s. 8-20, szcz. s. 14 („,bestialstwa ukraińsko-niemieckie”); J. Ostaszewski, Powstanie Warszawskie, w: Antologia... nieobecnych, s. 21-120, szcz. s. 62-64, 68 („Ukraińcy, Kubańcy"); A. Pomian-Dowmuntt, Powstanie Warszawskie (Zarys problematyki), Londyn 1946, w: Antologia... nieobecnych, s. 121-194, szcz. s. 180, 181 („Własowcy”); A. Chruściel „Monter”, Powstanie Warszawskie, Londyn 1945-1946/1948, w: Antologia... nieobecnych, s. 226-255, szcz. s. 240 („kozacy Własowa”); A. Borkiewicz, Powstanie Warszawskie 1944, Warszawa 1957; J. Kirchmayer, Powstanie Warszawskie, Warszawa 1959; Ludność cywilna w czasie Powstania Warszawskiego, t. I-III, red. Cz. Madajczyk, Warszawa 1974; Pamiętniki żolnierzy baonu AK „Zośka”. Powstanie Warszawskie, t. I-III, red. T. Sumiński, P. Sikorski, S. Wyganowski, J. Snitko-Rzeszut, Warszawa 2013: i in. 
To planowanie uległo szybkiej erozji z chwilą wybuchu Powstania Warszawskiego, gdy doszło do chaosu kompetencyjnego na styku Wehrmacht, policja i SS. Wówczas w stałej gotowości bojowej znajdowały się nie tylko oddziały policji i SS, lecz także pododdziały tyłowe Wehrmachtu (osłony mostów, szkoły wojskowe, warsztaty naprawcze wojsk pancernych, a także żandarmeria polowa i strzelcy krajowi - Landesschützen) oraz Luftwaffe (80 pułk artylerii przeciwlotniczej [Flak-Regiment 80] ${ }^{18} 23$ Dywizji Artylerii Przeciwlotniczej [23 Flak-Division], personel naziemny lotnisk, wojska łączności) podporządkowane Generalleutnantowi Stahelowi. Było to łącznie 13 tys. żołnierzy i policjantów, a dodatkowo 3 tys. artylerzystów z Luftwaffe. Tymczasem plan alarmowy dowódcy policji i SS w Warszawie, SS-Brigadeführera und Generalmajora der Polizei Paula Ottona Geibla z lipca 1944 r. zakładał użycie następujących sił: 15 tys. żołnierzy Wehrmachtu, 13 tys. żołnierzy Luftwaffe, 4 tys. żołnierzy Waffen SS, 4 tys. funkcjonariuszy Schutzpolizei, Werkschutz, Bahnschutz, Technische Nothilfe, co miało dawać 36 tys. ludzi ${ }^{19}$.

Himmler natychmiast rozpoczął gorączkowe poszukiwanie oddziałów, które mogłyby zostać szybko użyte do stłumienia Powstania Warszawskiego. Przede wszystkim Niemcy utworzyli improwizowane oddziały alarmowe oraz grupy bojowe ze szkół wojskowych i policyjnych oraz batalionów zapasowych, szkolnych, policyjnych itd. Do Warszawy skierowali też część jednostek cudzoziemskich podległych Wehrmachtowi, Ordnungspolizei (Schutzmannschaften), Sicherheitspolizei i Waffen-SS, a wycofanych właśnie z Białorusi i Nadbałtyki. Z całą stanowczością należy podkreślić, że nie były to w większości oddziały pierwszoliniowe, które wówczas walczyły z sowiecką 2 Armią Pancerną. Początkowo siły pacyfikujące stolicę liczyły około 10 tys. ludzi, natomiast w skład Korpsgruppe Bach (pod dowództwem SS-Obergruppenführera und General der Polizei und General der Waffen SS Ericha von dem Bacha weszło drugie tyle policjantów oraz żołnierzy Luftwaffe, Waffen SS i Wehrmachtu ${ }^{20}$.

${ }^{18}$ W skład 80 pułku artylerii przeciwlotniczej, dowodzonego przez Oberstleutnanta Joachima von Wietersheima (do 22 IX 1944 r. i zastąpionego przez Oberstleutnanta Franza Rubescha) wchodziły: (od 1 VIII 1944 r.) sztab, 1-4/115 ciężki kolejowy dywizjon artylerii plot - s[chwere].115 (E[isenbahn]) - druga wersja mówi tylko 1 i 2 baterii, natomiast 3 i 4 bateria 115 (E) miały walczyć na południu pod Dęblinem z oddziałami 1 Armii Polskiej; (od 1 IX 1944 r.) sztab, 1-6/gem.[ischte mieszany] 235 (v[erlegbar — półstała]); sztab, 1-6/gem.296 (v); sztab, 1-6/gem.661 (v) i sztab, 1-4/le.769 (v); oraz (od 1 X 1944) gem. I./50 (mot.); gem. I./54 (mot.); le.769 (v). Zob. G. Tessin, Verbände und Truppen der deutschen Wehrmacht und Waffen-SS im Zweiten Weltkrieg 1939-1945, t. VI: Die Landstreitkräfte 71-130, Osnabrück 1972, s. 55; oraz http://www.ww2.dk/ground/flak/flargt80. html [dostęp: 1 V 2015].

${ }_{19}$ Powstanie..., dok. 101 (Protokół przesłuchania komendanta garnizonu Warszawa gen. Reinera Stahela [Moskwa], 25 VIII 1945), s. 613; J. Bańbor, Siły niemieckie i przedsięwzięcia wokół Warszawy (VIII-X 1944), s. 1, 2 (mps ze zbiorów autora); D. Glantz, The Soviet-German War 1941-1945: Myths and Realities: A Survey Essay, A Paper Presented as the 20th Anniversary Distinguished Lecture at the Strom Thurmond Institute of Government and Public Affairs Clemson University October 11, 2001, Clemson, South Carolina, s. 83, 84; H. von Krannhals, Der Warschauer Aufstand 1944, Frankfurt am Main 1962, s. 120, 121 (niemiecki autor dołączył do wymienionych sił: wschodniopruski 4 [1145] pułk grenadierów, liczący 1100 żołnierzy, oraz batalion zapasowy Dywizji Spadochronowo-Pancernej [Strzelecko-Spadochronowo-Pancernej] „Hermann Göring” [960 żołnierzy], pominął zaś oddziały podporządkowane Oberfeldkommandantur 225 Generalleutnanta Wernera Schartowa - m.in. Sicherungs-Bataillon 944); R. Moorhouse, The German View of the Warsaw Rising 1944, w: www.polish resistance-ak.org/PR_WWII_texts_En/18_Article_En.rtf [dostęp: 21 III 2014]; S. Płoski, Niemieckie materiały do historii powstania warszawskiego, Warszawa 1958, s. 48, 49.

${ }^{20} \mathrm{~W}$ połowie sierpnia siły tego doraźnie powstałego związku taktycznego osiągnęły stan 21463 ludzi. Tymczasem zestawienie z 19 IX 1944 r. ze składem Korpsgruppe Bach wykazywało dwadzieścia cztery 
Największym ochotniczym oddziałem cudzoziemskim użytym w stolicy była wydzielona część brygady szturmowej RONA (Waffen-Sturm-Brigade RONA) — wówczas przemianowanej na 29 Waffen-Grenadier-Division der SS (russische Nr. 1) — pod dowództwem Waffen-Brigadeführer der SS und Generalmajor Bronisława Kamińskiego. Oddział ten miał wyraźnie rosyjski charakter, choć trafiali się w jego szeregach pojedynczy ochotnicy białoruscy, ukraińscy, kozaccy, a podobno nawet Polacy ze Kresów Wschodnich ${ }^{21}$. Do działań przeciw AK sztab brygady/dywizji wybrał 1500-1700 mężczyzn. Po naradzie z oficerami Kamiński utworzył 2 sierpnia na wniosek szefa sztabu, Waffen-Obersturmbannführera der $\mathrm{SS} /$ podpułkownika Szawykina, czterobatalionowy pułk szturmowy (zwany też zbiorczym) wzmocniony półbaterią zdobycznych haubic $122 \mathrm{~mm}$ oraz plutonem pancernym (cztery T-34 i jedno SU-76). Oddziałem kierował dowódca 2 pułku zbiorczego RONA, WaffenSturmbannführer der SS Iwan Frołow ${ }^{22}$, o czym zeznawał przed Smierszem: „Po przejściu m. Pietrokau [Petrikau — obecnie Piotrków Trybunalski] 7 [właściwie 3] sierpnia Kamiński wezwał dowódców jednostek na naradę, podczas której ogłosił: «Dostałem rozkaz wyznaczenia jednego pułku do udziału w pewnej operacji. W tym celu z każdego pułku trzeba wydzielić po jednym b[atalio], nie mniejszym niż 400 osób». Na tejże naradzie dowódcą pułku zbiorczego zostałem mianowany ja, szefem sztabu pułku kapitan [Waffen-Hauptsturmführer der SS] Noczowkin. Wyznaczonym ludziom rozkazano, by byli gotowi do wyjazdu samochodami. Ósmego [czwartego] pułk ześrodkował się 4 km na południowy zachód od Warszawy we wsi Raków i rozlokował się na noc"23.

Po 5 sierpnia Niemcy podporządkowali Rosjanom 2 kompanię Armee Panzerjäger Abteilung 743, wyposażoną w dwanaście-czternaście niszczycieli czołgów Jagdpanzer 38 (t) Hetzer. W czasie walk powstańcy uszkodzili krótkotrwale kilka niszczycieli czołgów, a łącznie wspomniany oddział stracił dwa Hetzery podczas walk na Ochocie i w Śródmieściu. W grę wchodziło też wspieranie RONA przez Sturmgeschütz Ersatz Batterie 200, wyposażonej w cztery działa szturmowe Sturmgeschütz III Ausf. E. (przestarzałe na front, ale znakomicie sprawdzające się w walkach miejskich $)^{24}$.

oddziały o łącznej liczebności 14006 żołnierzy. Zob. Archiwum Akt Nowych, Mikrofilmy Aleksandryjskie (dalej AAN) T-311, rol. 218, kl. 472.

${ }^{21}$ Informację o „kilku Polakach” bez odwołania do źródła można znaleźć w jednej z najlepszych (czterotomowej) monografii poświęconej kwestiom kolaboracji z Niemcami w czasie drugiej wojny światowej. Zob. Ludność cywilna, op. cit., t. I (zeznania Stanisława Trojanowskiego), s. 237, 238; D. Littlejohn, Foreign Legions of the Third Reich, t. IV, San Jose 1987, s. 312.

${ }^{22}$ Iwan Frołow, ur. 1906 r., Swinucha (rej. rodniczkowski, ob. saratowski) - zm. 1947, Moskwa, Rosjanin, obywatel ZSRS, członek WKP(b) od 1930 r., żonaty, troje dzieci, wykształcenie — 7 klas, w okresie od 1928 do 1942 r. w RKKA, awansując do stopniu majora i stanowiska szefa sztabu, a następnie dowódcy 133 pułku strzeleckiego 72 (sam przyznawał się dla niepoznaki do 77) DS, zapewne z powodu dowodzenia od sierpnia 1937 r. tym pułkiem przez Andrieja Własowa. Frołow przeżył wojnę, a nie - jak wcześniej się wydawało - zginął przy ulicy Srebrnej. Następnie służył w szeregach 1 Dywizji KONR. Po wojnie trafił do łagru nr 256, gdzie był poddany śledztwu przez Smiersz. Iwan D. Frołow został skazany na karę śmierci przez Kolegium Wojskowe Sądu Najwyższego ZSRS w dniach 30-31 XII $1946 \mathrm{r}$.

${ }^{23}$ Powstanie..., dok. 104 (Protokół przesłuchania dowódcy zbiorczego pułku brygady RONA mjr. Iwana Frołowa [łagier nr 256]; 10 VI 1946), s. 631; dok. 107 (Protokół przesłuchania dowódcy zbiorczego pułku brygady RONA mjr. Iwana Frołowa, b.m.w., 16 VII 1946), s. 647; dok. 109 (Własnoręczne zeznanie dowódcy zbiorczego pułku brygady RONA mjr. Iwana Frołowa, 1 IX 1946), s. 661-663.

${ }^{24}$ Kamiński został zwerbowany w 1940 r. przez NKWD jako agent pod pseudonimem „Ultramaryn” w celu rozpracowywania zesłanych do Łokotia trockistów — choć, jak donosił lejtnant GB Gurow, nie wykonywał należycie swoich zadań. Nadal wiele wątpliwości sprawia wyjaśnienie udziału RONA 
Zgodnie z tym mjr Frołow zeznał: „Oprócz tego żołnierzom zbiorczego pułku zezwolono na zupełnie bezkarne grabienie ludności cywilnej. Takie polecenie wydał Kamiński. Ponadto pododdziały zbiorczego pułku brały udział w prowadzeniu przymusowej ewakuacji ludności cywilnej z Warszawy. Ludziom pozwolono wtedy wziąć ze sobą minimalną ilość przedmiotów pierwszej potrzeby, [natomiast] majątek pozostawiony w mieszkaniach ulegał rozgrabieniu”. Pułk RONA przez pierwsze dziesięć dni walk z powstańcami, od 4 do 14 sierpnia, znajdował się na Ochocie, rabując i gwałcąc, a także mordując na terenie kolonii Staszica oraz Instytutu Radowego im. Marii Skłodowskiej-Curie przy ul. Wawelskiej 16. Natarcie prowadzone 8 sierpnia wspierała broń pancerna RONA: „Trzeciego dnia [od rozpoczęcia walk na Ochocie] przybyły cztery czołgi, natarcie kontynuowano, jednak po przejściu kwartału pułk znowu dostał się pod ogień powstańców. Dwa czołgi, które przedostały się naprzód, zostały przez powstańców podpalone, a dwa pozostałe zawróciły. Natarcie także zostało wstrzymane" ${ }^{, 25}$.

Po pierwszych walkach RONA utworzyła dla mieszkańców Ochoty obóz przejściowy przy ul. Grójeckiej (tzw. Zieleniak — na terenie obecnego targowiska przy Halach Banacha), gdzie Rosjanie pastwili się nad warszawiakami, a w szczególności warszawiankami. Zapewne maltretowanie ludności cywilnej było związane z odreagowaniem wysokich strat przez żołnierzy pułku RONA, sięgających w pierwszym tygodniu 30 proc. (sam Frołow przyznawał się do 10-15 proc.) zabitych i rannych w stosunku do stanu wyjściowego. W toku dalszych walk z powstańcami, oczyszczając sąsiedztwo Alei Jerozolimskich, podkomendni Frołowa zajęli 14 sierpnia szpital Dzieciątka Jezus przy ul. Nowogrodzkiej: „Jednocześnie z uprowadzeniem mężczyzn wprowadzono na teren szpitala bataljon kozaków armji Kamińskiego [sic!], którzy przeszło 2 tygodnie grabili szpital, mieszkania prywatne, terroryzowali chorych i pozostały personel, niewolili pielęgniarki, służbę kobiecą, a nawet i chore szpitalne" - pisał w sprawozdaniu dyrektor szpitala Konrad Okolski. Wymaga podkreślenia fakt, że Rosjanie koncentrowali się w sierpniu 1944 r. na grabieżach kosztowności, zegarków, pieniędzy oraz gwałtach na mieszkankach Ochoty, a nie na mordowaniu warszawiaków, co było domeną niemieckich oddziałów policji i żandarmerii, wyszkolonych w eksterminacji ludności cywilnej, wchodzących w skład Kampfgruppe Reinefarth pod dowództwem SS-Gruppenführera und General der Polizei Heinza Reinefartha ${ }^{26}$. Zresztą już od 9 (lub 16) sierpnia oddział Frołowa

w Powstaniu Warszawskim. Znane jest zdjęcie przedstawiające podoficera RONA w czarnym mundurze czołgisty z artylerzystą w mundurze feldgrau ze Stu.Gesch.Ers.Bttr 200. Zob. Powstanie Warszawskie 1944 w dokumentach z archiwów służb..., dok. 104 (Protokół przesłuchania dowódcy zbiorczego pułku brygady RONA mjr. Iwana Frołowa przez naczelnika Wydziału Specjalnego OKR łagru 256 mjr. gwardii Dworkina, 10 VI 1946), s. 631; dok. 109 (Własnoręczne zeznanie dowódcy zbiorczego pułku brygady RONA mjr. Iwana Frołowa, 1 IX 1946, b.m.w.), s. 663-667; N. Bączyk, Panzertruppen a Powstanie Warszawskie, Warszawa 2014) s. 26-28, 67-69; R. Bielecki, W zasiegu PAST-y, Warszawa 1994, s. 270, 271; H. V. Krannhals, op. cit., s. 361; J. Wroniszewski, Ochota 1944, Warszawa 1976, s. 635, 693; Д. Жуков, И. Ковтун, 29-я гренадерская дивизия СС «Каминский» (dalej: 29-я гренадерская), Москва 2009, s. 134, 135, 169, 170.

${ }^{25}$ Powstanie..., dok. 107 (Protokół przesłuchania dowódcy zbiorczego pułku brygady RONA mjr. Iwana Frołowa, b.m.w., 16 VII 1946), s. 649; dok. 109 (Własnoręczne zeznanie dowódcy zbiorczego pułku brygady RONA mjr. Iwana Frołowa, 1 IX 1946), s. 663-665.

${ }^{26}$ Archiwum Instytutu Pamięci Narodowej, Główna Komisja Badania Zbrodni Niemieckich w Polsce (dalej: AIPN, GK) 166/7: Szpital Dzieciątka Jezus z Warszawy, L. Dz. 31, Sprawozdanie, 9 IV 1945, k. 8-15; Protokół przesłuchania świadka — Konrada Okolskiego, 10 XI 1945, k. 16-19; Memorjał dotyczący zniszczeń i okrucieństw niemieckich w Instytucie Radowym im. Marii Skłodowskiej-Curie, ul. Wawelska 16, k. 51-55. 
był podporządkowany Kampfgruppe Rohr dowodzonej przez Generalmajora Günthera Rohra, a część żołnierzy RONA pozostawała do 23 sierpnia w rejonie Śródmieścia ${ }^{27}$.

Początki legendy o krwawych Rosjanach pobrzmiewają w zeznaniu kandydata na VManna: „Porucznik Haeske, 2 komp[ania] bat[alionu] «Benthin», stanowisko bojowe przy Eisgrubenstrasse [ul. Chłodnej] $51^{28}$ oddalone o $800 \mathrm{~m}$ od Markthalle [Hali Mirowskiej], doprowadził Ukraińca Teodora Misiejuka, ur. 17.11.23, ujętego przez oddział szturmowy w piwnicy przy Eisgrubenstrasse, gdy ukrywał się pod stertą łachmanów [...].

Powstańcy boją się najbardziej Kozaków i Ukraińców, ponieważ Kozacy mordują wszystkich zbiegłych [z szeregów powstańczych].

Wydaje mi się, że gdyby Kozacy się wycofali i na ich miejsce wprowadzono by niemieckie oddziały, znaczna część partyzantów z bronią, a przede wszystkim ludność cywilna przeszłaby na drugą stronę. Na zwycięstwo nikt z partyzantów już nie liczy.

$\mathrm{M}$ [isiejuk] jest gotów ponownie przejść do partyzantów jako inf[ormator] i wykonać ewentualne polecenia, ale stawia warunek, żeby w miejscu przejścia nie było ani Kozaków, ani Ukraińców"29.

Pułk RONA pod dowództwem Frołowa walczył o Dom Turystyczny przy pl. Starynkiewicza, Dworzec Pocztowy przy Al. Jerozolimskich oraz kamienice pomiędzy ulicami Srebrną i Żelazną. To tam RONA poniosła 22 VIII 1944 duże straty: „[...] Zbiorcza kompania 16. batalionu całkiem niemal wyginęła. [...] Stało się to w następujący sposób: kompania zajęła parter i piętro pewnego budynku. Żołnierze porozłazili się po całym domu, szukając kosztowności, żywności i wódki. Zaś Polacy, co znajdowali się w piwnicach i na górnych piętrach, otworzyli ogień z pm-ów i obrzucili [ich] granatami oraz butelkami zapalającymi, tak, że zniszczyli całą kompanię" - wspominał Iwan Waszeńko, podkomendny Frołowa. Wspomniane budynki kilkakrotnie przechodziły z rąk do rąk.

Tak jeden $\mathrm{z}$ oficerów RONA opisywał zaangażowanie Rosjan w walkach przeciwko powstańcom: „Przez półtora-dwa tygodnie [pułk] brał udział w tłumieniu powstania w Warszawie, po czym został wycofany [po kolejnych dwóch tygodniach dozoru w kordonie] tej operacji, jakoby z powodu niezadowalających [wyników] działań przeciwko powstańcom, i powrócił do rejonu mias. Ratibor [miasta Racibórz], gdzie znajdowała się brygada [RONA] po dokonaniu przemarszu z terytorium ZSSR. Jest mi wiadomo, że w wyniku operacji, przeprowadzonej przez pułk pod kierunkiem Frołowa, pułk nie wziął jeńców, a ilu było zabitych i rannych, nie wiem. Wiem, że jako łupy wzięto kilka motocykli i jeden samochód osobowy. Żadne inne dane o operacji pułku nie są mi znane"30.

\footnotetext{
${ }^{27}$ Grabieże i gwałty ominęły byłego prezydenta RP Stanisława Wojciechowskiego, który cudem ocalał ze spalonego przez żołnierzy domu przy ul. Lubeckiego 15. Sąsiedzi twierdzili, że został wywieziony do Gołąbek przez Niemców (co sugerują autorzy powstańczego bedekera, choć był to rejon działania pułku RONA). Zob. J. S. Majewski, T. Urzykowski, Przewodnik po powstańczej Warszawie, Warszawa 2012, s. 248; Д. Жуков, И. Ковтун, 29-я гренадерская..., s. 174-176.

${ }^{28}$ Stanowisko bojowe przy Eisgrubenstrasse [ul. Chłodnej] 51 sąsiadowało z parcelą przy ul. Chłodnej 47-49, na której dominowały ruiny oficyny wypalonego olbrzymiego, na 1500 osób, kinoteatru „Kometa” i dawnego budynku fabrycznego, Następną w kierunku ul. Żelaznej parcelę zajmował równie pokaźny dawny browar Machleida przy ul. Chłodnej 45, a sięgający po róg ul. Wroniej 47 i ul. Krochmalnej 66.

${ }^{29}$ Powstanie..., dok. 48 (Protokół przesłuchania powstańca Teodora Misiejuka [przez SS-Hauptscharführera i KOA Heckhausena w obecności majora policji ochronnej Sarnowa], Warszawa, 20 sierpnia 1944), s. 247-249.

${ }^{30}$ Powstanie..., dok. 105 (Protokół przesłuchania oficera brygady RONA Aleksandra Akułowa przez oficera operacyjnego OKR „Smiersz” łagru 256 lejtnanta Szykałowa, 20 VI 1946), s. 637 oraz aneks; dok. 2 (dziennik Iwana Waszeńki), s. 1083, 1085.
} 
Żołnierze 1 pułku RONA zostali podporządkowani dopiero nocą 23/24 sierpnia Kampfgruppe Schmidt. Rosyjski oddział został najpierw rozmieszczony między Powązkami a Dworcem Gdańskim, a po trzech dniach zluzowali go Niemcy. Tymczasem świadek wydarzeń Stanisława Wysmułek zapamiętała, że miało to miejsce wcześniej: „Powstańcy przebywali w naszym domu [ul. Inflancka 1] do dn. 14.VIII.1944 r. Popołudniu tego dnia od strony Dworca Gdańskiego wkroczyły oddziały w mundurach niemieckich — żołnierze rozmawiali po rosyjsku". Ta relacja pozwala sądzić, że część pułku RONA mogła zostać wcześniej wycofana ze Śródmieścia. Z tą wersją mogą współgrać zeznania dowódcy oddziału przed Smierszem - Frołow twierdził, że „19 VIII 1944 r., potem, jak pułk nie wywiązał się z jednego z zadań podczas wyjścia na rz[ekę] Wisłę, został wyprowadzony z Warszawy w celu przeczesywania terenów leśnych na północny zachód od Warszawy" ${ }^{\text {31 }}$.

Następnie Niemcy przerzucili podkomendnych Frołowa do zewnętrznego pierścienia wojsk w Puszczy Kampinoskiej. Raporty SD wskazywały na rosnące zagrożenie ze strony oddziałów partyzanckich. Ich zadaniem było niedopuszczenie do połączenia się partyzantów spoza Warszawy z powstańcami, co doprowadziło pod koniec sierpnia do walk z Grupą „Kampinos” Armii Krajowej na kierunkach Sieraków-Pociecha i Truskaw-Pociecha, Zaborów Leśny i wzgórze 94. Kilkakrotne natarcia Rosjan zostały odparte przez Polaków za cenę trzech zabitych i siedemnastu rannych. RONA straciła trzydziestu jeden zabitych i czternaście padłych koni. „Npl [Nieprzyjaciel] obsadza miejscowości: Laski, Sieraków, Truskaw, Izabelin, Bożęcin i Zaborów, starając się opanować południową i południowo-wschodnią lizjerę lasu"32.

Tak sytuacja wyglądała z perspektywy oddziału por. „Orlika”: „W okolicach Dąbrowy miał czekać na nas por. Dolina [Adolf Pilch] w sile 500 ludzi. Por. Doliny nie zastaliśmy, ponieważ miał potyczkę z nplem. Por. Dolina rozbił nplowi parę samochodów. Tutaj wpadliśmy na obławę urządzoną na niego. Npl. wystąpił w sile 2000 ludzi, około 100 samochodów. Stoczyliśmy walkę ze stratami 3 zabitych, 5 rannych. Po 6 godz. walk wycofaliśmy się o zmroku [ze] wsi Adamów, zabierając rannych" W rzeczywistości Rosjan zostało tylko 900 żołnierzy po walkach w Warszawie ${ }^{33}$.

${ }^{31}$ AAN, T-175, rol. 226 kl. 2764533-534, Der Befehlshaber der Sicherheitspolizei und des SD im Generalgouvernement, IV 1 - nr 1976/44 g. (Lagebericht Nr. 13), 21 VIII 1944 (dokument przekazany przez p. Jana Bańbora); AIPN, GK 166/1100, k. 104 (GKBZN, t. VI akt w sprawie zbrodni hitlerowskich w okresie Powstania Warszawskiego i zburzenia Warszawy [dalej: Tom VI]; Protokół przesłuchania świadka Stanisławy Wysmułek z Mendygrałów, 5 I 1948); Powstanie..., op. cit., dok. 103 (Protokół przesłuchania dowódcy zbiorczego pułku brygady RONA mjr Iwana Frołowa przez zastępcę naczelnika OKR „Smiersz” łagru 256 kapitana Magorowskiego i oficera operacyjnego OKR „Smiersz” Szykałowa, 31 V 1946), s. 627; A. Borkiewicz, op. cit., s. 253, 354.

${ }^{32}$ AAN, T-175, rol. 226 kl. 2764533-534, Der Befehlshaber der Sicherheitspolizei und des SD im Generalgouvernement, IV 1 - Nr. 2029/44 g. (Polnische WB. Konzentrierungzur AK zumangeblichen Eintsatz von Warschau und Auslösung der Aktion „Burza”), 19 VIII 1944 (dokument otrzymany dzięki uprzejmości p. Jana Bańbora), oraz Archiwum Państwowe m. st. Warszawy (dalej: APW), 1724/ II-3, (Rozkazy i meldunki Grupy „Kampinos” AK od 21 do 31 VIII 1944 - Meldunek sytuacyjny [mjr „Okoń”]; 31 VIII 1944), k. 52: oraz J. Koszada „Harcerz”, Grupa Kampinos. Partyzanckie zgrupowanie Armii Krajowej walczące w Powstaniu Warszawskim, Warszawa 2007, s. 59, 60 (autor wspomina o walkach pod Brzozówką rozgrywających się 10 i 22 sierpnia - straty RONA: dwudziestu ośmiu zabitych i trzydziestu rannych; Polaków: pięciu zabitych i czterech rannych).

${ }^{33}$ APW, 1724/II-6 (Rozkazy i meldunki Grupy „Kampinos” AK, wykaz osobowy żołnierzy, ewidencja rzeczowa 1944- [1945], [Niepodpisany i niezatytułowany raport o oddziale „Orlika”]; 13 X 44 r.), k. 35 . 
W nocy 2/3 września osiemdziesięcioosobowy oddział AK por. „Doliny” rozbił w Truskawiu III batalion RONA. Zginęło 100-250 podkomendnych Frołowa, a akowcy zdobyli dużo broni (m.in. jedną armatę $75 \mathrm{~mm}$, dwa moździerze $82 \mathrm{~mm}$, dwa cekaemy, 23 erkaemy, 16 peemów, 48 kb, 10 tys. sztuk amunicji i zapasy żywności). Ceną za to było ośmiu zabitych i dziesięciu rannych Polaków. Następnej nocy pododdział z II szwadronu wachm. Józefa Niedźwieckiego ps. „Lawina” i IV szwadronu ppor. Aleksandra Pietruckiego ps. „Jawora” zaatakował kolejny oddział RONA w Marianowie — Rosjanie mieli stracić stu zabitych i dwudziestu rannych. Jeden Polak zginął, a pięciu zostało rannych. Polacy zdobyli dwa erkaemy, siedem peemów i kilkadziesiąt kb/kbk. Walka pod Truskawiem okazała się ostatnią akcją Rosjan z pułku szturmowego RONA w okresie powstania. „Swoją odmowę dalszego uczestnictwa w działaniach bojowych motywowałem nieobecnością Kamińskiego, wezwanego do sztabu wojsk niemieckich w Krakowie, i jego rozkazem niepodejmowania dalszych operacji pod jego nieobecność, posiadaniem na uzbrojeniu pułku przestarzałych typów broni, poniesionymi w walkach stratami, stanowiącymi 10-15 proc. [faktycznie prawie połowa], zmęczeniem ludzi” - zeznawał Frołow ${ }^{34}$.

Celnym komentarzem dotyczącym zakresu dezinformacji propagandy Goebbelsa, a zarazem opinią o zbrodniach RONA były słowa Aleksandra Pierchurowa: „Jednak po dokonaniu haniebnej rozprawy z ludnością Warszawy, który to fakt poznała cała światowa społeczność, Niemcy widocznie chcieli umyć ręce i zwalić winę za okrucieństwo wobec ludności cywilnej na jednostki «ochotnicze», w tym na pułk zbiorczy brygady KAMIŃSKIEGO. Wyraźnie pod naciskiem dowództwa niemieckiego sprawę FROŁOWA rozpatrywano w kręgu oficerów. Wszedłem służbowo do pokoju, gdzie zebrali się oficerowie na czele z podpułkownikiem BIEŁAJEM, zastępcą KAMIŃSKIEGO (sam KAMIŃSKI już wtedy nie żył), i słyszałem, jak przemawiający oficerowie potępiali bestialskie, sadystyczne działania FROŁOWA wobec ludności cywilnej Warszawy. FROŁOW próbował nieporadnie usprawiedliwiać się. Sprawa FROŁOWA została przez podpułkownika BIEŁAJA umorzona i po Operacji Warszawskiej mógł on znowu zajmować stanowisko dowódcy 1 pułku brygady KAMIŃSKIEGO aż do momentu włączenia brygady w skład jednostek ROA i zakończenia jej funkcjonowania jako samodzielnej brygady szturmowej RONA, tj. do października 1944 roku [Waffen-SturmBrigade der SS RONA]",35.

\footnotetext{
${ }^{34}$ AIPN, GK 162/704, (AOK 9, Ia, Nr. 4456/44,, Fernschreiben KR, An [...] Obkdo.H.Gr.Mitte, nachr.: Ob.Gr.Fhr.v.d.Bach; 29 VIII 1944), k. 51; GK 661/4 (E.K. Sipo Kampfgruppe Reinefarth, Bericht über Banden in den Kapinoswäldern; 3 IX 1944), k. 2; Powstanie..., dok. 107 (Protokół przesłuchania dowódcy zbiorczego pułku brygady RONA mjr. Iwana Frołowa przez starszego śledczego 1 Wydziału 4 Oddziału Zarządu Kontrwywiadu „Smiersz” Grupy Sowieckich Wojsk Okupacyjnych w Niemczech starszego lejtnanta Własowa, 16 VII 1946), s. 647; aneks, dok. 2 (dziennik Iwana Waszeńki), s. 1087-1089. ${ }^{35}$ „Postawa ludności uległa na pewien czas, między 10 a 20 sierpnia, zmianie, kiedy po pojawieniu się w Warszawie kozacy KAMIŃSKIEGO podjęli działania przeciwko polskim kobietom i dzieciom. Powołując się na to, AK rozwinęła działalność propagandową, twierdząc, że będą się oni odnosić w ten sposób do wszystkich polskich kobiet i dzieci. Wówczas wielu związało się z AK lub w jakiś inny sposób okazywali jej wsparcie" - pisał w sprawozdaniu niemiecki urzędnik z NSDAP. Co ciekawe, słowa Fischera konfrontuje z zeznaniami generała Luftwaffe prowadzonymi w mniej komfortowych warunkach, choć wysłuchanymi przez naczelnika 2 Oddziału Zarządu Głównego „Smiersz” pułkownika Kartapowa: „Nie mogłem powstrzymać niemieckich żołnierzy od represji wobec ludności polskiej. Kiedy było już wiadomo, że żołnierze niemieccy grabią domy spokojnych mieszkańców, wydałem rozkaz, zgodnie z którym żołnierze mogli zabierać wszystko, co zechcą z tych domów, w których zaczął się pożar. [...] Muszę przyznać, że zezwoliłem na grabienie ludności cywilnej Warszawy, gdyż uważałem, że tak czy inaczej żołnierzy niemieckich nie da się przed tym powstrzymać”. Zob. Powstanie..., dok. 3
} 
Po wycofaniu z rejonu Warszawy pułk RONA trafił do miasteczka Schammerau (Samborowice), położonej dziesięć kilometrów od Ratibora (Raciborza). Stamtąd niemiecka komisja odesłała go na wirtemberski poligon w Münsingen, gdzie pod dowództwem SSBrigadeführer und Generalmajor (der Waffen-SS und Polizei Christopha Diehma była rozwijana rosyjska 29 Waffen-Grenadier-Division der SS (russische Nr. 1). Konsekwencją ataku na oddział RONA było spacyfikowanie polskiej Grupy Kampinos, które Niemcy przeprowadzili w ramach typowych działań „Bandenbekämpfung” znanymi jako operacje „Sternschuppe I” i „Sternschuppe II"36.

Często żołnierzy RONA lub Kozaków utożsamiano z własowcami lub Ukraińcami. Pierwsi często nosili na rękawie mundurów naszywkę z krzyżem Patée i akronimem RONA cyrylicą, natomiast drudzy z niebieskim krzyżem św. Andrzeja na białym tle i skrótem ROA również cyrylicą. Natomiast Rosyjska Armia Wyzwoleńcza była jedynie określenie nieistniejącego faktycznie związku, bo przydzielanego batalionami do niemieckich jednostek. A pierwsze oddziały KONR sprzymierzonego z III Rzeszą zaczęły powstawać od listopada 1944 r. Były to m.in. wehrmachtowskie: 600 Dywizja Piechoty (1 Dywizja KONR), 650 Dywizja Piechoty (2 Dywizja KONR) oraz 1 Szturmowa Brygada Przeciwpancerna „Russland” - więc nie mogły wziąć udział w pacyfikowaniu powstania w polskiej stolicy.

\section{Nie tylko kryminaliści i dyscyplinarnie ukarani}

Bardziej złowrogą sławę zdobył w stolicy pułk specjalny SS pod dowództwem SSStandartenführera Oskara Dirlewangera, którego niemal połowę składu tworzyli obcokrajowcy z terenów ZSRS. Oddział liczył w końcu lipca 1944 r. 865 (881) żołnierzy ${ }^{37}$. Oba jego pododdziały dotarły do Warszawy dzień po dniu - I batalion (SS-Obersturmführer/ SSHauptsturmführer i Hauptmann der Polizei Maier) już 5 sierpnia. SS-Sdr.Rgt. Dirlewanger dojechał do Warszawy z Lycka (Ełk) przez Treuburg (Olecko)-Lötzen (Łuczany)-Ortelsburg (Szczytno)-Zichenau (Ciechanów)-Wyszogród. II batalion (SS-Sturmbannführer Steinhauer) oraz kompanie: kaemów, moździerzy i bateria artylerii ppanc. wraz z żołnierzami azerskimi dojechały ciężarówkami następnego dnia w drugim rzucie przez Arys (Orzysz)-Johannisburg (Pisz)-Ostrołękę-Modlin. Żołnierze SS-Sonderregiment Dirlewanger walczyli w ramach

(Sprawozdanie gubernatora dystryktu warszawskiego Ludwiga Fischera dla generalnego gubernatora Hansa Franka, b.m.w., b.d. [grudzień 1944]), s. 1137; Powstanie..., dok. 101 (Protokół przesłuchania komendanta garnizonu Warszawa gen. Reinera Stahela, [Moskwa]. 25 VIII 1945), s. 615; oraz dok. 106 (Protokół przesłuchania oficera brygady RONA Aleksandra Pierchurowa, b.m.w., 8 VII 1946), s. 643.

${ }^{36}$ J. Kirchmayer, op. cit., s. 366; J. Koszada, op. cit., s. 87-96; J. Krzyczkowski, Konspiracja i powstanie w Kampinosie, Warszawa 1961, s. 364-374, 383-387: Д. Жуков, И. Ковтун, 29-я гренадерская..., s. $186,187$.

${ }^{37}$ Niemcy tworzyli pierwszy batalion, natomiast Rosjanie i Ukraińcy służyli w drugim batalionie. Oba liczyły po cztery kompanie. Po Powstaniu Warszawskim w skład SS-Sonderregiment rozwiniętego 15 października w SS-Sturmbrigade Dirlewanger zaczęli wchodzić też więźniowie polityczni, czyli niemieccy komuniści i socjaldemokraci określani jako „wrogowie ruchu narodowosocjalistycznego”. Przez szeregi jednostki Dirlewangera przewinęło się po 3 X 1944 r. 1910 dawnych członków KPD i SPD. Zob. H. P. Klausch, Antifaschisten in SS-Uniform. Schicksal und Widerstand der deutschen politischen KZ-Häftlingen Zuchthaus- und Werhmachts gefangenen in der SS-Sonderformation Dirlewanger, Bremen 1993, s. 206; F. MacLean, The cruel hunters. SS-Sonderkommando Dirlewanger Hitler's most notorious anti-partisan unit, Atglen 1998, s. 124, 125, 179, 203, 204; R. Michaelis, „Dirlewanger”, Warszawa 2005, s. 16; Д. Жуков, И. Ковтун, Охотники за партизанами. Бригада Дирлевангера (dalej: Охотники..., Москва 2013, s. 344. 
Angriffsgruppe Dirlewanger na południe od ulicy Wolskiej, podporządkowani większemu związkowi - Kampfgruppe Reinefarth. SS-Obergruppenführer Erich von dem Bach zauważył podczas pierwszej inspekcji pozycji na Woli, że ,[...] panuje zamieszanie i bezhołowie. Każdy oddział strzelał w innym kierunku, nikt nie wiedział, do kogo należy strzelać, i cała sytuacja była trudna do rozwiązania”. Nieład zauważony przez dopiero co mianowanego dowódcę „,bezhołowia” przy warszawskiej cerkwi św. Jana Klimaka w drodze do sztabu Reinefartha przy skrzyżowaniu Litzmannstädter Straße (ul. Wolska) z ul. Sokołowską mógł się odnosić do podwładnych Dirlewangera. Choć ci ostatni do walki wchodzili pod cerkwią prawosławną św. Jana Klimaka na Woli, znajdowali 300-400 metrów na południe od tego miejsca, które widział von dem $\mathrm{Bach}^{38}$.

SS-Sonderregiment Dirlewanger był wspierany do 15 sierpnia podczas walk przez 1 kompanię Armee Panzerjäger Abteilung 743, wyposażoną w czternaście niszczycieli czołgów Jagdpanzer 38 (t) Hetzer. Oś pierwszego szturmu tych dwóch batalionów pułku specjalnego SS przebiegała ulicami Dworską (obecnie ul. Marcina Kasprzaka), Karolkową, Ogrodową, Chłodną (Eisgruber Straße), Elektoralną oraz Krochmalną przez Hale Mirowskie, pl. Mirowski, pl. Żelaznej Bramy i Ogród Saski (Sachsen Garten). Żołnierze Dirlewangera dotarli do placu Piłsudskiego (Adolf-Hitler Platz), placu Teatralnego (Theaterplaz) i gmachu Sądów przy Lesznie (obecnie Al. Solidarności). Dirlewanger z bronią w ręku niejednokrotnie sam dawał podwładnym przykład bezwzględności na pierwszej linii ognia. Oczywiście nie miał nic przeciwko rzucaniu do szturmów ulicznych nieostrzelanych i dyscyplinarnie ukaranych żołnierzy dopiero co wypuszczonych z wojskowych więzień - którzy masowo ginęli we wspomnianym ataku z Woli ku Śródmieściu. „Nasi żołnierze warunkowo zwolnieni, którzy siedzieli w obozie koncentracyjnym osiem tygodni wcześniej, ponieśli ciężkie straty. [...] Kule latały koło mnie. Drzwi były zamknięte, ale przynajmniej łuk nad drzwiami dawał mi trochę osłony. Rozejrzałem się dookoła. Inni żołnierze wycofali się ku odrzwiom. Część leżała na ulicy. Tam nie było szans do natarcia. Musieliśmy wchodzić do domów i eliminować strzelców. Wiele drzwi było zamkniętych i musieliśmy je otwierać kolbami karabinów lub eksplozjami granatów. Gdy już byliśmy w domach, wszystko przebiegało raczej szybko. Nie mogliśmy powstańcom dawać czasu na reakcję" — wspominał podwładny Dirlewangera. Stopniowo temu dowódcy były podporządkowane: jedna z lekkich baterii wydzielona z 80 Flak Regiment, jedna z kompanii Panzer Abteilung (Fkl [Funklenk Panzer czołgi kierowane radiem]) 302 z Sturmpanzer-Kompanie z.b.V. 218 (osiem-dziesięć sztuk Sturmgeschütz IV Sturmpanzer IV - $150 \mathrm{~mm}$ samobieżnych haubic StuH 43/1 L/12) kpt. Kellmanna, część 4 kompanii wsparcia Aserb. FeldBtl. I/111, 1 pluton 654 Pioniere Battailon, 1 drużyna miotaczy ognia Krone (osiem Flammenwerfer 41) ${ }^{39}$.

\footnotetext{
${ }^{38}$ Relacja von dem Bacha o Powstaniu Warszawskim, „Dzieje Najnowsze” 1947, r. I, z. 1, s. 302; Zburzenie Warszawy. Zeznania generałów niemieckich przed polskim prokuratorem członkiem polskiej delegacji przy Międzynarodowym Trybunale Wojennym w Norymberdze, „Dzieje Najnowsze” 1947, r. I, z. 2 (zeznanie Ericha von dem Bacha), s. 32, 33, i (zeznanie Rodego) s. 90.

${ }^{39}$ Niemiecki podoficer, walczący w SS-Sdr.Rgt. Dirlewanger, nic nie wspomniał o mordach na ludności cywilnej [sic!], sygnalizując, że była ewakuowana do obozu przejściowego. Zob. Anonim, The SSSonderkommando Dirlewanger. A Memoir, red. R. Michaelis (dalej: Memoir), Atglen 2013, s. 61; N. Bączyk, op. cit., s. 26-28, 48-52 [Pz.Abt. (Fkl) 302. wszedł do akcji 13 VIII, zaś Stu.Pz-Komp z.b.V. 218 od 15 VIII]; W. Bartoszewski, Dni walczacej stolicy. Kronika Powstania Warszawskiego (dalej: Dni...), Warszawa 2004, s. 46, 52, 56, 59; A. Borkiewicz, op. cit., s. 97, 145, 148, 149; T. Bór-Komorowski, op. cit., s. 236, 237; J. K. M. Hanson, Nadludzkiej poddani próbie. Ludność cywilna Warszawy w powstaniu 1944 r., Warszawa 2004), s. 46, 47; J. Kirchmayer, op. cit., s. 244-246; H. v. Krannhals,
} 
Kolejny opis znalazł się nieco dalej we wspomnieniach przytaczanego niemieckiego uczestnika walk: ,[...] «Tłum» [z SS-Sonderregiment Dirlewangera — przyp. aut.] przybył, spojrzał i zaczął szturmować. Około 50 ludzi rzuciło się poprzez ulicę. Około 30 żołnierzy legło na ulicy i nie ruszyło się więcej. Pozostali zniknęli w domu i w ciągu następnych dziesięciu minut zarówno trupy, jak i żyjący ludzie wylatywali z okien czwartego i piątego piętra. Podwładnych Dirlewangera nie powstrzymywały długie przemówienia. Oto jak oczyszczaliśmy domy w Warszawie”. Wyjaśnia to, dlaczego żołnierze SS-Sdr.Rgt. Dirlewanger nie byli brani do niewoli. Oddziały niemieckie nacierające z Woli dotarły już 6 sierpnia do Ogrodu Saskiego i pałacu Brühla, gdzie był odcięty generał Stahel. Następnie oddział Dirlewangera, podporządkowany Stahelowi, zajął pozycje wzdłuż ulicy Senatorskiej oraz pl. Teatralnego. SS-Sonderregiment zaatakował w kierunku ulic Bednarskiej i Karowej, osiągając ul. Dobrą, aż pod dom na rogu z ul. Karową. Równocześnie siły Angriffsgruppe Dirlewanger wdarły się na pl. Bankowy i szturmowały barykadę na ul. Bielańskiej, Ratusz i pałac Blanka oraz opanowały ogołocone mury Zamku Królewskiego ${ }^{40}$.

Drugim wspomnianym wsparciem dla SS-Sonderregiment Dirlewanger było po 8 sierpnia prawie tysiąc żołnierzy po wykroczeniach dyscyplinarnych. „Oni wzmocnili I batalion i wypełnili II batalion. Ponieważ przybyli w swoich mundurach Kriegsmarine, Luftwaffe i Heer, kompanie wyglądały teraz całkiem pstrokato. Motywacja w tych szeregach nie istniała. Najwyraźniej więzienia Wehrmachtu nie były bardzo ładne i tam, skąd przychodzili, [stawali się] niczym więcej niż mięsem armatnim (jak my też, podejrzewam). Dowódcy nie dbali, jak dużo ich padnie. Może oni nawet myśleli, że to jeszcze lepiej [...]. Kontyngent po dyslokacji, inaczej niż w typowej biurokracji, został porzucony i my, dowódcy plutonów, nie raportowaliśmy liczb (jak wielu mieliśmy rannych i zabitych)" — wspominał anonimowy podoficer $\mathrm{SS}^{41}$.

Jednym z dyscyplinarnie ukaranych za dezercję był Volksdeutsch pochodzenia węgierskiego przesłuchiwany po wojnie przez mjr. W. Czechowskiego z Polskiej Misji Wojskowej Badania Niemieckich Zbrodni Wojennych: „Zameldowałem się u pewnego oficera, który wkrótce potem wysłał mnie do 1 szturmowej kompanii pierwszego batalionu. «Ty będziesz obsługiwał karabin maszynowy w 3 grupie [drużynie]» — powiedział mi dowódca kompanii. Udałem się do grupy [drużyny]. Razem ze mną liczyła [ona] 9 ludzi. Wrażenie, jakie robili, nie było najlepsze. Kilku leżało na ziemi, inni grali w karty lub palili, obok każdego znajdowało się naczynie lub szklanka z winem albo wódką. Nieporządek, brud i złe powietrze - nic, co by mi mogło sprawić przyjemność. Kompania miał przerwę w boju, jednak stale oczekiwano alarmu. Dlatego musiałem pozostać przy grupie. Moje zajęcie ograniczało się do obserwacji innych, którzy nie zwracali na mnie żadnej uwagi.

[...] Siedmiu z nich to byli przestępcy kryminalni raz lub kilkakrotnie karani, wszyscy mieli za sobą pięcio- lub ośmioletni pobyt w obozie koncentracyjnym. Tylko jeden nie był

op. cit., s. 214, 308-312; F. L. MacLean, op. cit., s. 180-182; Polskie sity zbrojne w II wojnie światowej, t. III: Armia Krajowa, red. S. Lityński, A. Sawczyński, Londyn 1950, s. 822, 823.

${ }^{40}$ Niemcy (najbardziej możliwe, że to policjanci z Angriffsgruppe Dirlewanger) rozstrzelali w Halach Mirowskich kilkuset mężczyzn, którzy wcześniej uprzątali arterię Wolska-Chłodna-Ogród Saski. Zob. Ludność cywilna, op. cit., t. I (zeznania Joanny Kryńskiej), s. 319-322; W. Bartoszewski, 1859 dni Warszawy (dalej: 1859 dni...), Kraków 1984), s. 625, 626; idem, Dni..., s. 97; A. Borkiewicz, op. cit., s. 152, 154, 155, 167, 177, 178, 181, 314, 315; T. Bór-Komorowski, op. cit., s. 248; J. Kirchmayer, op. cit., s. 262, 263, 295-297; F. L. MacLean, op. cit., s. 181, 187, 188; R. Michaelis, Die Grenadier Divisionen der Waffen-SS, t. III, Erlangen 1995, s. 172, 173; Д. Жуков, И. Ковтун, Охотники.., s. 346, 347.

${ }^{41}$ Anonim, Memoir, s. 64. 
przestępcą. By wykorzystać czas, oglądałem powierzony mi karabin maszynowy i zajmowałem się nim.

Pewnego poranka uderzono na alarm. W szybkim tempie skierowano się do środka miasta. «Dla wzmocnienia» - nazywało się to. Zluzowane kompanie, zmęczone i brudne, szły nam naprzeciw. «Kompania szturmowa X jest wykończona!», «Szef padł również!», «Morderczy opór!» — słyszałem takie i tym podobne okrzyki. Rozlegały się pojedyncze wystrzały. Na jednym dużym placu przyjął nas silny ogień karabinów maszynowych i pistoletów maszynowych. Byli ranni. Odprawiono ich na tyły. Dalej naprzód! Wreszcie osiągnęliśmy bramę pałacu Brühla. Kilka nurkowców [samolotów bombowych Junkers Ju-87] przeleciało z łoskotem $\mathrm{w}$ kierunku południowo-zachodnim, zrzucając swoje ciężkie bomby w odległości zaledwie 100 m"42.

Nadal nie jesteśmy w stanie określić, czy w masakrach wolskich brali udział Ukraińcy i Rosjanie, czy też Niemcy służący pod Dirlewangerem. Sama liczebność SS-Sonderregiment Dirlewanger - ponad ośmiuset ludzi na początku walki (nawet z liczącymi prawie tysiąc osób „dyscyplinarnymi” uzupełnieniami) — uniemożliwiała dokonywanie masowych rozstrzeliwań i z dużym prawdopodobieństwem za autorów masakr na Woli można uznać za niemieckie pododdziały Schutzpolizei, Feldgendarmerie oraz oddziały turkiestańskie i azerskie podległe Angriffsgruppe Dirlewanger. Dojrzali wiekiem mężczyźni niemieccy (niespełniający wymagań do walk frontowych) potrafili podnieść swoje karabiny Mauser wz. 1898 i oddać strzał do nieruchomych celów stojących pod ścianą, co wcześniej udowodnił Reserve Polizei Bataillon 101. Podobnego typu zbrodnią była nieludzka hekatomba prawosławnego sierocińca przy ul. Wolskiej 149, o czym wspominał saper Mathias Schenk z PionierBataillon 46, wspierającego pułk SS Dirlewangera: „Wysadziliśmy drzwi, chyba do szkoły. Dzieci stały w holu i na schodach. Dużo dzieci. Rączki w górze. Patrzyliśmy na nie kilka chwil, zanim wpadł Dirlewanger. Kazał zabić. Rozstrzelali je, a potem po nich chodzili i rozbijali główki kolbami. Krew ciekła po tych schodach. Tam w pobliżu jest teraz tablica, że zginęło 350 dzieci. Myślę, że było ich więcej, z pięćset”. Zginął wówczas także proboszcz prawosławnej parafii św. Jana Klimaka, archimandryta Teofan (Teodozy Protasiewicz), inni duchowni, personel świecki i wierni szukający azylu w parafialnym domu przy ul. Wolskiej. W podobny sposób Schenk opisywał zbrodnię i gwałty w jednym ze szpitali, o czym opowiadał H. P. Klauschowi: „Tak stałem się świadkiem wydarzeń, które są tak paskudne i straszne, że mogłem je opisać dopiero teraz, po 40 latach. Klnę się na moje słowo - to prawda"43.

\footnotetext{
42 Powstanie..., dok. 112 (Protokół przesłuchania G. Davidhazy’ego), s. 725-727.

${ }^{43}$ Dirlewanger urządzał publiczne egzekucje dezerterów, chłosty, wieszanie i rozstrzeliwanie podwładnych. Faktyczny autor wykonania rozkazu Hitlera (po wojnie adwokat) Reinefarth został uniewinniony po dwudziestoletnich przepychankach w RFN-owskim aparacie sprawiedliwości, notabene zdominowanym - co nie powinno dziwić - przez niezdenazyfikowanych sędziów, masowo uniewinniających sprawców zbrodni wojennych w latach pięćdziesiątych i sześćdziesiątych XX w., czy niezdenazyfikowanych prokuratorów odrzucających hurtowo polskie (czytaj: komunistyczne) wnioski o ukaranie niemieckich przestępców, którzy dożywali godnej emerytury w Bundesrepublice. Zob. M. Burleigh, Trzecia Rzesza. Nowa historia, Kraków 2010, s. 794; K. Kąkolewski, Co u pana słychać. Biała księga/ Sprawa Dolezalka, Warszawa 1986, s. 64, 67; H. P. Klausch, op. cit., s. 113; N. Sennertag, Kat Warszawy, Warszawa 2009, s. 265-428 (zwraca uwagę fenomenalny i drobiazgowy opis nieskuteczności niemieckiego aparatu sprawiedliwości w latach pięćdziesiątych i sześćdziesiątych XX w); Д. Жуков, И. Ковтун, Охотники, ор. cit., s. 364 (rosyjscy autorzy piszą о 15 tys. -16 tys. ofiar „dirlewangerowców”); W. Nowak, A. Kuźniak, Mój warszawski szat. Druga strona powstania, „Duży Format”, 23 VIII 2004, s. 4.
} 
Wart podkreślenia jest fakt, że ten związek był luźno podporządkowany Kampfgruppe Reinefarth, której dowódca po wojnie zwalił całą winę za zbrodnie wojenne na podległych sobie nieżyjących oficerów niższej rangi. „Ja potępiam te egzekucje nie od dziś, ale wtedy także. Dochodziły mnie meldunki i odwoływałem egzekucje. Ale tylko wtedy, gdy dochodziły mnie meldunki. [...] Przestępstwa wojenne zostały dokonane, to jest ustalone, ale ja to wiem z przewodu sądowego. Byli to ludzie Dirlewangera i Kamińskiego, którzy myśleli, że nadeszła godzina zemsty. [...] A więc z brygady Dirlewangera: nie mogę powiedzieć na pewno, ale osobiście jest mi wiadomo, że rabowali, gdyż ludzi Dirlewangera widziano z materiałami na garnitury, z produktami żywnościowymi itd., które znaleziono w piwnicach zdobytych domów, przeważnie zburzonych, w których nikogo nie było. Dirlewanger poniósł wielkie straty w ciągu tego czasu. Ja wiem, że on przybył z 700 ludźmi i kazał sobie stale przysyłać tabor".

Poza zbrodniami wojennymi Dirlewanger i jego podwładni zajmowali się grabieżami. Więzień Dachau Hans Brun potwierdzał, że w pacyfikacji Powstania uczestniczyli esesowcy, będący wcześniej zawodowymi kryminalistami, którzy dziewczętom niechcącym „zdjąć pierścionków, odcinali palce”. Inny przestępca Heinrich Weinand wspominał: „Na każdym palcu były złote obrączki. [...] Jeśli któraś dziewczyna się opierała, związywali jej ręce, a pod spódnicę wpychali granat ręczny”. Sam Dirlewager miał przejawiać „milczącą tolerancję” dla grabieży. Zagrabione przedmiotyprzekazywał do SS-HA, nie zapominając o własnym domu w Esslingen, gdzie wysłał wagon z rzeczami, co potwierdzili po wojnie jego sąsiedzi ${ }^{44}$.

Związek szturmowy Dirlewangera wzmocnili dyscyplinarnie ukarani żołnierze przybywający do pułku od 8 do 10 sierpnia z więzień wojskowych - 300 z Glatz, 400 z Anklam. Kolejnymi byli ochotnicy azerscy i turkiestańscy, biorący udział od 12 sierpnia w szturmie na Stare Miasto. Pięciobatalionowa Angriffsgruppe Dirlewanger, licząca 29 oficerów oraz 1999 szeregowców i podoficerów, zajmowała pozycje wzdłuż placów Zamkowego i Teatralnego do Wisły aż po ulice Boleść i Rybaki. Związek Dirlewangera brał udział w ciężkich dwutygodniowych zmaganiach o Ratusz, ruiny Zamku Królewskiego i katedry św. Jana oraz ich staromiejskie okolice. Następnie 1 września SS-Sonderkommando zaatakowało ulicami Kanonią, Piwną, Świętojańską i dotarło na Rynek Starego Miasta, Nowomiejską i Krzywe Koło, co faktycznie zakończyło obronę Starówki. Po tym żołnierze Waffen SS (w tym Turkiestańczycy podlegający Dirlewangerowi) wymordowali rannych w części szpitali rozlokowanych w budynkach przy Długiej 7, Freta 10, Kilińskiego 1/3, Miodowej 24 oraz Podwalu 25 i $46^{45}$.

\footnotetext{
${ }^{44}$ Powstanie..., dok. 110 (Protokół przesłuchania dowódcy grupy bojowej gen. Heinza Reinefartha, b.m.w., 19 IX 1946), s. 681, 682; H.-P. Klausch, op. cit., s. 114-116.

${ }^{45}$ Od połowy sierpnia SS-Sonderregiment Dirlewanger składał się z dwóch organicznych batalionów, wspieranych przez I i II/Ostmuselmanische SS-Regiment 1 (jeszcze od walk na Białorusi), II/ Sonderverband „Bergmann” (od 7 VIII 1944 r. bez 7 kompanii), czterech (od 6 VIII 1944 r. już tylko 1, 2 i 3 oraz plutonu z 4) kompanii I/111. batalionu (azerskiego), 2 i 4 kompanii batalionu żandarmerii polowej „Walther”, 1 plutonu 654 batalionu saperów, ośmiu miotaczy ognia z 1 drużyny batalionu „Krone” oraz baterii (pięć armat plot. pięć $20 \mathrm{~mm}$ ) 80 pułku artylerii przeciwlotniczej. Oddział w walkach na placu Zamkowym wspierał „wehrmachtowski” Panzer-Abteilung (Fkl) 302 majora Reinelta. Wcześniej trzy ciężkie transportery min „Borgward” z tego oddziału zaatakowały barykadę zamykającą ul. Podwale. Jeden z nich stał się sprawcą masakry; gdy wtoczono pojazd na ulicę Kilińskiego, wybuchł ukryty w nim pięciusetkilogramowy ładunek prasowanego trotylu. Zginęło ponad trzysta osób. Zob. Э. Абрамян, Забытый Легион. Неизвестные страницы соединения специального пазначения „Бергманн”, Книга 1, Ереван 2005, s. 153, 154; W. Bartoszewski, Dni..., s. 113, 114, 240, 241; A. Borkiewicz, op. cit., s. 193, 212-215, 217, 221, 224, 227, 228, 252, 253, 255, 256, 266,
} 
Kolejnym celem SS-Sonderregiment Dirlewanger stało się Powiśle, które było elementem koncentrycznego uderzenia wespół ze szturmem Czerniakowa przez Kampfgruppe Rohr. Jeszcze na przełomie sierpnia i września oddział otrzymał uzupełnienia w postaci 300 dyscyplinarnych skazańców z wojskowych więzień Anklam i 500-600 z Glatz. Niemcy, wspomagani przez artylerię, wyrzutnie rakietowe Nebelwerfer i „Stukasy” przełamali już 2 września obronę zgrupowania kapitana Cypriana Odorkiewicza ps. „Krybar”, zastąpionego następnego dnia przez majora Stanisława Błaszczaka ps. „Róg”. Krwawe działania potwierdzał meldunek dzienny z 6 września niemieckiej H. Gr. „Mitte”: „W Warszawie dwóch strzelców z obsługi karabinów maszynowych grupy szturmowej Dirlewangera zlikwidowało 152 bandytów [cywilów - przyp. aut.] na jednym z dziedzińców". Po tych atakach Powiśle padło nocą z 6 na 7 września. Skoncentrowanej nowoczesnej technice wojskowej Polacy mogli przeciwstawić zapał i „koktaile Mołotowa”, co znowu uwidoczniło skuteczność niemieckiej taktyki eliminowania kolejnych dzielnic, które wzajemnie sobie tylko w niewielkim stopniu pomagały ${ }^{46}$.

Następnie Dirlewanger atakował w pasie między Świętokrzyską a Chmielną i wdarł się 7 września na ul. Warecką. Natomiast po utknięciu 10 sierpnia kolejnych szturmów na ul. Górskiego SS-Sonderkommando skierowało się w rejon Muzeum Narodowego i uderzało wzdłuż ulic Książęcej oraz Ludnej. Dirlewanger odciął 12/13 września Czerniaków od Śródmieścia. Powstańczemu zgrupowaniu podpułkownika Jana Mazurkiewicza ps. „Radosław" niewiele pomogło chaotyczne wsparcie polsko-sowieckie z praskiego brzegu. Desant I oraz III batalionu 9 pułku 3 Dywizji Piechoty (około 1250 tzw. berlingowców bez należytego wsparcia artyleryjskiego i lotniczego) 1 Armii Wojska Polskiego, przeprowadzony 15/16 i 16/17 września, przedłużył agonię Czerniakowa o siedem dni. Dalsze straty SS-Sonderregiment Dirlewanger spowodowały dwukrotne uzupełnienie stanów osobowych oddziału - w połowie września przez 300 więźniów z Torgau-Brückenkopf, natomiast w końcu miesiąca przez trzy kontyngenty: 200-250 z Anklam, 300 z Bruchsal oraz 1400 z obozu karnego SS i policji Strafvollzugslager der SS und Polizei Danzig-Matzkau (obecnie Gdańsk-Maćkowy, ul. Starogardzka). Łącznie dawało to 3700-3850 dyscyplinarnie ukaranych żołnierzy i policjantów, którzy byli doraźnymi posiłkami dla szybko topniejących stanów osobowych pułku ${ }^{47}$.

267, 298, 299; T. Bór-Komorowski, op. cit., s. 280, 281, 300, 301; J. Kirchmayer, op. cit., s. 304, 318, 329, 358, 469, 483; H. P. Klausch, op. cit., s. 122; H. v. Krannhals, op. cit., s. 381-383; F. L. MacLean, op. cit., s. 189-191; Д. Жуков, И. Ковтун, Охотники..., s. 350, 351.

${ }^{46}$ Borkiewicz podaje, że atak na Powiśle Kampfgruppe Reinefarth (w jej szeregach SS-Sonderregiment) rozpoczęła 4 września. Kirchmayer oraz Żukow i Kowtun wspominają o 3 września. Dirlewanger dowodził wówczas sześcioma batalionami $(\mathrm{I} / \mathrm{D}=333$, II/D=315, I. turk. $=275$, III. turk. $=300$ żołnierzy, I/111. i II./„Bergmann” oraz był wspierany przez kompanię dział szturmowych. Zob. Anonim, Memoir, s. 64, 65; W. Bartoszewski, Dni..., s. 246, 247; idem, 1859 dni..., s. 700-702; A. Borkiewicz, op. cit., s. 446, 447, 466, 467, 470; T. Bór-Komorowski, op. cit., s. 316-318; J. Kirchmayer, op. cit., s. 368 , 369; H. P. Klausch, op. cit., s. 122; R. Michaelis, Der Weg zur 36. Waffen-Grenadier-Division der Waffen-SS, Rodgau 2004, s. 65; Д. Жуков, И. Ковтун, Охотники, s. 354; A. Munoz, German SS, Police \& Auxiliary Forces in Poland. Part V-1944 \& The Warsaw Uprising, w: „Axis Europa. The Journal of the Axis Forces, 1939-1945” 1998, nr 15, s. 19-23; „Dzieje Najnowsze” 1947, r. I, z. 1, s. 321.

${ }^{47}$ Walki o Czerniaków przetrzebiły obie strony. Zachowana dokumentacja ekshumacyjna PCK sygnalizuje, że polegli żołnierze Dirlewangera zostali pochowani na terenie przylegającym do hotelu sejmowego od strony ul. Górnośląskiej, ,,idąc w stronę Sejmu”. Część z nich została ekshumowana po powojennym zniszczeniu cmentarza, co uniemożliwiło zlokalizowanie i wydobycie wszystkich ciał do dnia dzisiejszego. Zob. Powstanie..., dok. 112 (Protokół przesłuchania G. Davidhazy’ego), s. 731; W. Bartoszewski, Dni..., s. 313, 325; idem, 1859 dni..., s. 715-720; R. Bielecki, M. Strok, Żotnierze Powstania Warszawskiego. Dokumenty z archiwum Polskiego Czerwonego Krzyża, t. III, Ekipa XI, Meldunek 
Pod koniec powstania Dirlewanger dowodził jedynie 648 żołnierzami, tak więc jego straty bezpowrotne sięgnęły 2715 ludzi, co odpowiadało 308-314 proc. stanu wyjściowego! Związek podległy Dirlewangerowi był wówczas rozmieszczony nad Wisłą od Potoku (nadwiślańska część Marymontu) do mostu Kierbedzia. Mimo tak horrendalnych strat dowódca SS-Sonderregiment został awansowany do stopnia SS-Oberführera i odznaczony 30 września Krzyżem Rycerskim Żelaznego Krzyża za sukcesy swojego oddziału w pacyfikowaniu powstania - uroczysty awans i odznaczenie miało miejsce na Wawelu w obecności generalnego gubernatora Hansa Franka ${ }^{48}$.

\section{Kozaków było znacznie więcej}

Oddziały kozackie stanowiły jedną z najliczniejszych grup narodowościowych spośród cudzoziemców walczących z powstańcami. Tak zapamiętał dotarcie do Warszawy Kozak Wiktor Dudnikow: „Marszowy Stan wyszedł z Puszczy [Białowieskiej] na normalne drogi Polski Wschodniej. Upały zamieniły się w nieskończone deszcze. Taka radykalna zmiana pogody dała możliwość oderwania się od przeciwnika [2 Frontu Białoruskiego RKKA]. Przemęczeni ludzie i konie z trudem posuwali się w solidnych potokach ulew. Szli, padali, podnosili się i znowu szli. Wydawało się, że nie będzie końca dręczącej marszruty. Ale nagle wyjrzało słońce. Pojawiła się obfita karma dla koni. Po pięciodniowym przemarszu 6 zbiorczy pułk kozacki pod dowództwem pułkownika Żurawliowa, pierwszy wkroczył na obszar starego poligonu artyleryjskiego Dumska Wola [Zduńska Wola].

W trakcie marszu na poligon doszło do spotkania sowieckiej brygady pancernej. Miało to miejsce w Pradze, na prawym brzegu Wisły, naprzeciw [lewobrzeżnej] Warszawy. [...] Noc była ciemna, choć oko wykol. Wyszliśmy na sąsiednią ulicę i zatrzymawszy się natknęliśmy się na T-34. [...] I rozpoczęła się strzelanina. Pod osłoną nocy odeszliśmy na stanowiska swojego batalionu, wynosząc zabitego. Batalion odszedł nad brzeg Wisły ku umocnionemu przedmościu. Tam był rozlokowany dywizjon [bateria] artylerii przeciwlotniczej i dwie kompanie piechoty jako wzmocnienie. Całą pozostałą część nocy trwał bój. Świtem po [wydaniu] rozkazu batalion wycofał się do Warszawy. Tego samego dnia Warszawa powstała. Wydawało się, że całe miasto strzela. Bojem wyrwaliśmy się na szosę i odeszliśmy na Łomżę, a stamtąd poszliśmy [przez Płock] ku Dumskiej Woli. Pierwszy pułk konny był pozostawiony w Warszawie i dołączył do korpusu [Stanu Kozackiego] późną jesienią”. Luki w pamięci rozmyślającego „starego Kozaka” znacząco pozmieniały choćby samą marszrutę po opuszczeniu Puszczy Białowieskiej. Zapis równie dobrze mógł dotyczyć skierowanego do walki z powstańcami stolicy 3 pułku kozackiego pod dowództwem płk. Bondarenki (wcześniejszego dowódcy 5 kozackiego pułku kubańskiego) wraz

nr 4 z dn. 12 III 1945, Warszawa 1997, s. 85-87; A. Borkiewicz, op. cit., s. 559, 562-565, 568, 569, 577, 578, 579, 593, 594, 597, 615-617; J. Kirchmayer, op. cit., s. 371, 372, 386-388; H. P. Klausch, op. cit., s. 122; T. Bór-Komorowski, op. cit., s. 329, 330, 334-336; F. L. MacLean, op. cit., s. 189-196; Д. Жуков, И. Ковтун, ор. cit., s. 354-365; „Dzieje Najnowsze” 1947, r. I, z. 1, s. 321, 322.

${ }^{48}$ Według niepotwierdzonej relacji (niemieckiego jeńca - porucznika Luftwaffe Füssingera) Dirlewangera „dosięgła” sprawiedliwość po wojnie - opublikowali ją Michaelis i MacLean. Dirlewanger znalazł się we francuskim więzieniu w Altshausen pod pieczą polskich wartowników. Nie przeżył tego aresztu, bity do upadłego przez trzy noce. Dirlewanger został pochowany w tym miasteczku. Zob. W. Bartoszewski, 1859 dni..., s. 759; T. Bór-Komorowski, op. cit., s. 344-347; N. Davies, op. cit., s. 539; H. v. Krannhals, op. cit., s. 126; F. L. MacLean, op. cit., s. 191, 196 i 257; S. Płoski, Materiaty, op. cit., s. 17, oraz Д. Жуков, И. Ковтун, Охотники, s. 366; „Dzieje Najnowsze” 1947, r. I, z. 1, s. 305. 
z podporządkowanym mu pododdziałem kozackim dowodzonym przez chorążego wojsk kozackich (porucznika) I. Anikina ${ }^{49}$.

Oddziałem policyjnym był 209 kozacki batalion Schutzmannschaften sformowany w Warszawie z samodzielnych kompanii na trzy miesiące przed powstaniem. W maju oddziałem dowodził pułkownik Siergiej Krakowskij. Upowszechniły się też w relacjach i opracowaniach informacje o uczestnictwie w rzezi Woli dwustupięćdziesięcioosobowej kozackiej kompanii eskortowo-wartowniczej SD i kozackiego batalionu policji SS (mogły współtworzyć 209 batalion). „Kozacy, o ile mi wiadomo, podlegali Reinefarthowi. Wycofano ich po mniej więcej trzech tygodniach" — zeznawał po wojnie gubernator Fischer. Kilkuset Kozaków walczyło aż do początku października w ramach Kampfgruppe Schmidt. Dwaj żołnierze tego oddziału zostali odznaczeni Srebrnym i Brązowym Medalem 2 klasy z Mieczami Odznaczenia za Waleczność dla Narodów Wschodnich (Tapferkeitsauszeichnung fur Angehörige der Ostvölker 2. Klasse) — odpowiednio Vize-Korporal (starszy kapral) Gienadij Osmorkyn i Schutzmann (szeregowiec) Dmitrij Suchin za walki z powstańcami w trakcie służby w kordonie na terenie getta warszawskiego, przeciwdziałając kontaktom powstańców z oddziałami AK rozlokowanymi pod Warszawą ${ }^{50}$.

${ }^{49}$ W Stanie Kozackim (Казачий Стан) w ramach 4 Zbiorczej Kozackiej Brygady Piechoty (4 Сводная казачья пластунская бригада) znajdował się 3 zapasowy kozacki pułk piechoty (3 Казачий запасной пластунский полк) dowodzony przez starszynę wojsk kozackich (podpułkownik) Owsiannikowa, jego zastępcą był starszyna wojsk kozackich Żurawliow, co mogło odnosić się do opisanego „zbiorczego pułku kozackiego pułkownika Żurawliewa”. Inny rosyjski historyk wspomina o 1 pułku siniegorskim pod dowództwem ppłk. Żurawliowa. Stan musiał się wycofywać się przez Łomżę, Modlin, Płock, skąd jeden pułk został skierowany na krótko do Warszawy, a Stan Kozacki w Marszu (Marszowy Stan) trafił na poligon artyleryjski Burzenin-Sieradz-Zduńska Wola („Truppenübungsplatz Schieratz”). „3 pułk piechoty kozacki z niestrudzonym zapałem, odwagą i męstwem walczył przez siedem tygodni w krwawych i uciążliwych walkach ulicznych z powstańcami. Piąta część pułku oddała krew dla sprawy wyzwolenia Europy z bolszewizmem" - pisał w specjalnym rozkazie gen. Krasnow. Zob. В. Дудников, Воспоминания старого казака пережситом и размылиления о настоящем, w: „Материалы по истории русского освободительного движения 1941-1945 гг (статьи, документы, воспоминания)”, под редакцией А. В. Окорокова, часть 1, Москва 1997, s. 334; С. Дробязко, А. Каращук, Восточные легионы и казачьи части в Вермахте (dalej: Восточные легионы), Москва 2000, s. 38; С. И. Дробязко, Под знамёнами врага. Антисоветские формирования в составе германских вооружённых сил, 1941-1945 гz (dalej: Под знамёнами врага, Москва 2004, s. 234; A. Felchner, Wysiedlenia i przesiedlania w Sieradzkiem podczas II wojny św., „Biuletyn Okręgowej Komisji Badania Zbrodni przeciwko Narodowi Polskiemu w Łodzi”, t. III, Łódź 1994), s. 52-60; Эпопея Казачьего Стана под водительством походных атаманов С.В. Павлова И Т.И. Доманова в 1943-1945 г2., w: http://www.istmira.com/kazaki-mezhdu-gitlerom-i-stalinym/2444-yepopeya-kazachego-stanapod-voditelstvom.html [dostęp: 30 III 2015].

${ }_{50}$ Rosyjski autor uznał Kosaken Schuma Btl. 209 za ukraiński oddział. Archiwum Instytutu Pamięci Narodowej (AIPN), GK 107/20, (Schuma.-(Kos.) Batl. 209, Vorschlag zur Verleihnung der Tapferkeitsauszeichnung für Angehörige der Ostvölker 2. Klasse in Silber - Genady Osmorkyn; 9 XI 1944), k. 1; (Schuma.-(Kos.) Batl. 209, Vorschlag zur Verleihnung der Tapferkeitsauszeichnung für Angehörige der Ostvölker 2. Klasse in Bronze - Dmitrji Suchin; 9 XI 1944), k. 2; GK 661/9, (Kampfgruppe Schmidt; An Kampfgruppe Reinefahrth 6 X 1944), k. 69; (Vernehmung zur Person: Nikolai Sedackin, Siergiej Woboweikow, Nikolai Bohntscherskow, Aleksiej Bobrowski, Jwan Kumpan 3 X 1944), k. 70; Powstanie..., dok. 114 (Zeznanie gubernatora dystryktu warszawskiego Ludwiga Fischera pt. „Powstanie w Warszawie" [Protokół], 5 IV 1948), s. 747; C. Дробязко, А. Каращук, Восточные легионы, s. 42; idem, Восточные добровольйы в Вермахте, полиции и СС, Москва 2000), s. 44; С. Дробязко, Под знамёнами врага, s. 234. 
Stolicę Polski osiągnął IV batalion kozacki 57 pułku zabezpieczenia ppłk. Zwista(IV[Kos.]/ Sicherungsregiment 57) oraz 69 dywizjon kozacki dowodzony przez mjr. Wittmana (mowa też o mjr. Hansie Helmutcie Pirnerze, zastąpionym przez mjr. Wilhelma Fickermanna) — ale ich główne zadanie polegało na patrolowaniu kordonu i odgradzaniu partyzantów z Puszczy Kampinoskiej od Żoliborza. W oddziale służyli płk Eberhard Schmidt-Reinthaler oraz kapral Ferdinand Schäfer — obaj odznaczeni Złotym Krzyżem Niemieckim (Deutsches Kreuz in Gold) odpowiednio 29 VIII i 29 X 1944. Tam też służył rosyjski 580 dywizjon kawalerii Osttruppen. Dowodził nim kpt. Ernst Kalamorz, też odznaczony Deutsches Kreuz in Gold 1 IX 1944 r. za walki w Warszawie. O jednej z jednostek kawaleryjskiej po stronie niemieckiej wspomniał mieszkaniec ul. Senatorskiej: ,,...] Eskortę naszej grupy [objął] koło rogatki oddział Dońskich Kozaków, który przeprowadził nas do obozu przejściowego w Pruszkowie". Zgoła odmienne wrażenia miał inny warszawiak z ul. Inflanckiej, który zapamiętał, że ,[...] przybyli teraz Kozacy (mieli okrągłe czapki z otokiem z baranka) i ponownie zaczęli wyciągać z grupy kobiety, a następnie je gwałcić”. Ponadto w Warszawie walczył kozacki 572 batalion piechoty (płk Zinowiew), a według niektórych również kozacki 631 batalion piechoty ${ }^{51}$. Stany osobowe poszczególnych oddziałów kozackich przedstawiały się następująco: IV./57. pułk - 490, 69. dywizjon - 366, 580. dywizjon - 160, 572. batalion - 260.

Wyżej opisanych Kozaków mógł wspominać w meldunku por. „Dolina” — p.o. dowódcy Grupy „Kampinos”: „7.8.44. o godz. 12.00 utarczka 1. plut.[onu] w Lipkowie z Kozakami, a następnie o godz. 20.30 akcja całości w rej.[onie] Koczargi-Zielonka-WojcieszynWyględy-Bożęcin. Npl [Nieprzyjaciel] rozproszony w dniu nast.[ępnym] opuścił umocnienia, w tych wsiach robione $\mathrm{z}$ wielkim pośpiechem. Straty własne: 7 poległych, 2 rannych. Straty npla [nieprzyjaciela]: nieustalone, zdobyto 1 pistolet, $2 \mathrm{~kb}$ i amunicję ${ }^{, 52}$.

Najprawdopodobniej kozacki 572 batalion piechoty płk. Zinowiewa uczestniczący w operacji „Sternschuppe I” i „Sternschuppe II” (choć bardziej możliwym winowajcą był pułk zbiorczy SS RONA, W-Stubaf.d.SS Iwana Frołowa) wymieniony jest w meldunku „Dyrektora Tucholskiego” z 27 sierpnia: „Po południowej stronie Kampinosu grasuje grupa Kozaków, która dopuszcza się najgorszych gwałtów i ekscesów wobec naszej ludności. W dniu 26. VIII po południu napadła na m. Borzęcin gwałcąc niewiasty, mordując

${ }^{51}$ Ci Kozacy mogli nosić tarcze naramienne ROA na lewym rękawie, choć nie byli podporządkowani faktycznie czy chociażby teoretycznie strukturom kojarzonym z osobą generała Własowa. Ciekawostką jest, że w 69 dywizjonie kawalerii (określanym w dokumencie z drugiej połowy sierpnia jako Kosaken Regiment 69) służył w randze Unteroffiziera (kaprala) Francuz Eugene Lebowuer. Ponadto warta odnotowania jest liczebność Sicherungs-Regiment 57 - wg stanu z 1 VI 1944 r. liczył on 2701 żołnierzy (w tym 49 oficerów) oraz 213 Hiwi. Zob. AIPN, GK 166/1100 (GKBZN, t. VI; Protokół przesłuchania świadka Rudolfa Hermana; 13 III 1948), k. 72-73; (Protokół przesłuchania świadka Jana Przełomskiego; 14 I 1948), k. 106-107; GK 661/1 (Kampfgruppe Reinefarth, Einsatz von Kraftfahrzeugen; 15 VIII 1944), k. 1; GK 661/3, (E.K. Sipo Kampfgruppe Reinefarth; 21 VIII 1944), k. 15; GK 661/9, (Sicherungsverband major Jacob, Andie Kampfgruppe Reinefarth; 12 IX 1944), k. 47; (IV./Kos./Sich.Regt.57, Abt.Ia Az.15, Betr.: Feindpropaganda; 18 IX 1944) k. 54; (Kosaken-Batl. 572, An Die Kampfgruppe „,B”, Herrn Major Hahn, Feindl. Flugzettel.; 2 X 1944), k. 71; С. Дробязко. Под знамёнами врага, s. 234; S. Płoski, Materiały, op. cit., s. 16, 17; О. Романько, Мусульманские легионы во Второй мировой войне, Москва 2004, s. 217, 218.

${ }^{52}$ Co ciekawe, grabieży dokonywały również oddziały węgierskie („Węgrzy przeprowadzają dotkliwe rekwizycje krów, koni itp., zrabowali Bożęcin” - jak donosił „Dolina”. Zob. AIPN, GK 166/1100, k. 72-73 (GKBZN, t. VI; Protokół przesłuchania świadka Rudolfa Hermana; 13 III 1948); k. 106107 (Protokół przesłuchania świadka Jana Przełomskiego; 14 I 1948); APW 1724/II-1, k. 49 (Rozkazy i meldunki Grupy „Kampinos” AK od 1 do 12 VIII 1944 - Meldunek sytuacyjny z dnia 11.VIII.br.; 12 VIII 1944). 
ludność itp. Ludność polska wyczekuje ratunku ze strony oddziałów partyzantów polskich. Wykonanie akcji likwidacyjnej w stosunku do tej grupy Kozaków miałoby ogromne znaczenie pod względem podniesienia ducha ludności i jej zaufania do możliwości obronnych ze strony oddziałów polskich. Mam wrażenie, że grupą tą jest oddział przewijający się koło Lasek", ${ }^{, 3}$.

\section{Byli obywatele RP i ZSRS}

Do Warszawy trafiła też część złożonego z siedmiu kompanii, liczącego tysiąc żołnierzy, białoruskiego 13 batalionu policji pomocniczej Policji Bezpieczeństwa (Schutzmannschaft Bataillon der Sicherheitspolizei 13). Białoruską kadrę oficerską tworzyli przedwojenni podoficerowie WP i Armii Czerwonej, którzy zostali awansowani do „wschodnich” stopni — podporuczników (Zugführer) i poruczników (Oberzugführer) ${ }^{54}$. Oddział białoruski był wzmiankowany w Warszawie od 3 sierpnia, ochraniając budynki mieszkalne i urzędy niemieckie w dzielnicy policyjnej w rejonie alei Szucha, Róż i Ujazdowskich oraz w okolicach ulic Koszykowej i Wiejskiej. Najprawdopodobniej w pacyfikacji powstania wziął udział cały batalion, bez wspomnianej wyżej 4 kompanii ${ }^{55}$. Za udział $\mathrm{w}$ walkach z powstańcami Oberfeldwebel, czyli starszy sierżant Ilja Sanetz (Zaniec?) został odznaczony Złotym Medalem 2 klasy Odznaczenia za Waleczność dla Narodów Wschodnich (Tapferkeitsauszeichnung fur Angehörige der Ostvölker 2. Klasse in Gold). Ten białoruski podoficer ,znajdował się 13. 9. 44. w II plutonie 1 kompanii w dzielnicy Sielce, gdy został przesunięty tam na południowy front. Z powodu nie przejrzystego terenu [pokrytego] willami i ogrodami niemiecki dowód-

\footnotetext{
${ }^{53}$ AAN, T-175, rol. 226, kl. 2764450-2764496, a szcz. kl. 2764458-2764459 oraz 2764484-2764485 (Der HSSPF im GG, Ic BdS, Tgb.Nr. 138/44, Bericht über die Bandenlage im Monat September 1944; 10 X 1944); AIPN, GK 661/3, k. 54; (Kosaken-Batl. 572, An Die Kampfgruppe „B”, Herrn Major Hahn, Feindl. Flugzettel.; 2 X 1944); oraz APW, 1724/II-3, k. 28 (Rozkazy i meldunki Grupy „Kampinos” AK od 21 do 31. 08. 1944 - Pismo „Dyrektora Tucholskiego” do „Pana Majora Okonia”; 27 VIII 1944)

${ }^{54} \mathrm{~W}$ batalionie białoruskim służyli też Rosjanie i Polacy (ci najprawdopodobniej usunięci z oddziału w wyniku Polenaktion przeprowadzonej z białoruskiej inspiracji). Wśród Polaków można wymienić Jana Sucharzewskiego, aresztowanego za współpracę z podziemiem, czy wcielonego przymusowo Jana Benedyktowicza. Morale oddziału osłabło po wycofaniu z Białorusi, czego dowodem była 14 lipca dezercja całej (najprawdopodobniej 4.) kompanii, liczącej czterech oficerów, 19 podoficerów i 90 szeregowców na stronę 1 pułku ułanów Krechowieckich. Zob. J. Grzybowski, Pogoń między Orłem Białym, Swastyka i Czerwonq Gwiazdą. Białoruski ruch niepodległościowy w latach 1939-1956, Warszawa 2011, s. 318-321; A. Suchcitz, Dzieje 1. Pułku Utanów Krechowieckich 1941-1947, Londyn 2002, s. 295-297.

${ }^{55}$ Batalion Sipo (bez określenia jego numeru porządkowego) miał wchodzić w skład Kampfgruppe Rohr, której podlegały odcięte siły Geibla. Mogło to odpowiadać oddziałowi białoruskiemu. Zresztą OdB (Ordre de Bataille) wspomnianej grupy bojowej wykazywało od trzeciego tygodnia sierpnia jeszcze: pułk szturmowy (zbiorczy) RONA, pododdziały artylerii i saperów oraz mniejsze pododdziały podporządkowane SS-Brigadeführerowi Geiblowi (łącznie 6251 ludzi). Niemieckie dokumenty sygnalizują obecność Einsatzkommando SD na plebanii kościoła św. Wojciecha przy ul. Sokołowskiej i podporządkowania go Kampfgruppe Reinefarth. Zob. G. Tessin, Verbände und Truppen der deutschen Wehrmacht und Waffen-SS im Zweiten Weltkrieg 1939-1945, t. 11: Die Landstreitkräfte 501630, Osnabruck 1975, s. 338, 339; A. Borkiewicz, op. cit., s. 444; N. Sennerteg, op. cit., s. 156, 157; R. B. Birn, Die Siecherheitspolizei in Estland 1941-1944. Eine Studie zur Kollaboration im Osten, Padenborn-München-Wien-Zürich 2006, s. 29-31 [uprzejmie dziękuję za wskazanie tego opracowania p. Arkadiuszowi Karbowiakowi].
} 
ca plutonu [Zugführer] musiał swój oddział złożony z Białorusinów podzielić i przekazał Sanetzowi połowę swojego plutonu, ponieważ ostatni podoficer tego pododdziału poległ poprzedniego dnia. Po wyznaczeniu końcowego celu dowódca plutonu oddzielił się od Sanetza i obydwa półplutony [drużyny] nacierały niezależnie. Opór powstańców był bardzo mocny. Niemiecki dowódca plutonu zauważył szybko, że skrzydło dowodzone przez Sanetza wysforowało się do przodu. Chociaż Sanetzowi spadł na lewą stopę odłamek muru podczas walki i miał utrudnione [możliwości] natarcia do przodu, to rozwijał ten atak z niezmienioną siłą woli, był pierwszy u celu ataku i samodzielnie zaczął rozbudowę [osiągniętych] pozycji, gdy przedarł się do niego niemiecki dowódca plutonu. Sanetz przełamał jeden z najciężej bronionych odcinków na skutek swojej dzielności i swoich przymiotów dowódczych w niepowstrzymanym parciu naprzód szybciej niż sąsiednie oddziały, znacznie ułatwił im dalsze natarcie. Pozycja została przeniesiona do przodu przed nadchodzącą nocą, około godziny 2 i znów to był Sanetz, który jako pierwszy ze swoimi ludźmi zajął i rozbudował nową budowlę. Chociaż ta budowla leżała pod skrzydłowym ostrzałem. Gdy niemiecki dowódca plutonu został wezwany do swojego dowódcy odcinka, Sanetz załatwił jeszcze dwóch ukrytych Bandytów [powstańców], rzucając granatem ręcznym. [...] Sanetz jest ze swoim batalionem od 3 sierpnia 1944 w akcji na Feldherrnallee [ul. Puławska], w walkach na ulicach i w budynkach między Al. Szucha, a Al. Róż, w walkach o koszary huzarów ${ }^{56}$, na Dorf- und Soldatenstraße [ul. Wiejskiej oraz ul. Bończa ${ }^{57}$ ] i teraz na Sielcach, tak jak już wielokrotnie wcześniej w walkach z [«]Bandami[»] na Białorusi, dostarczył dowodów swojej dzielności. Dlatego proponuje Ilję Sanetza odznaczyć Tapferkeitsauszeichnung für Angehörigeder Ostvölker 2. Klasse in Gold, uważam go za szczególnie godnego otrzymania tego odznaczenia jako pierwszego w 13. batalionie". Tymczasem działania Białorusinów z 1/ Schuma Btl der Sipo 13 na Mokotowie były odbierane przez Polaków jako walki z Ukraińcami. Oddziały z koszar przy ul. Podchorążych obsadziły już od 9 września ulice Bończy i Sukcesorską, nacierając równoległymi ulicami Zakrzewską, Stępińską i Górską. Natarcie odpierały oddziały ppłk. Stanisława Kamińskiego ps. „Daniel” — główne siły batalionu „Ryś” dowodzonego przez rtm. Andrzeja Czajkowskiego ps. „Garda” (kompania specjalna, „Dywersja Bojowa”, dwa plutony kompanii „K 1” por. Mariana Ślifierza ps. „Wirski” z pułku AK „Baszta”). Dzięki przeciwnatarciu plutonu ,Jeleń” rtm. Lecha Głuchowskiego ps. „Jeżycki” zostały odbite zakłady przy ul. Stępińskiej. Ale i tak Niemcom udało się uzyskać możliwość transportu ul. Czerniakowską, która znalazła się poza skutecznym zasięgiem powstańczych granatników przeciwpancernych PIAT i zdobycznego „Panzerschrecka”. Nazajutrz kompanie batalionu „Ryś” wykorzystały przerwę w walkach na umocnienie bronionych pozycji. Już 11 września rozpoczął się intensywny ogień artylerii i moździerzy, który zapowiadał atak na Sielce. Dwie kompanie w sile 250 żołnierzy, wspierane przez dwanaście czołgów i dział szturmowych, rozwinęły się do natarcia na wysokości ul. Bończy, ale kilkakrotne próby zaatakowania pozycji rtm. „Gardy” nie powiodły się do godz. 18, choć Białorusini okopali się na bliskim

\footnotetext{
${ }^{56}$ Najprawdopodobniej chodzi o koszary Grodzieńskiego Huzarskiego Pułku Lejb-Gwardii (przy dzisiejszej ul. 29 listopada nr 3b). Wówczas ulica nosiła nazwę Huzarskiej, choć nie była to nazwa oficjalna. Drewniane baraki koszarowe zastąpiła jeszcze przed 1893 r. zabudowa murowana. Po odzyskaniu niepodległości doszło ok. 1925 r. do ich przebudowy według projektu Kazimierza Tołłoczki na koszary Oddziału Przybocznego Prezydenta RP. Ponadto mieściły się w budynkach jeszcze koszary 1 dywizjonu artylerii konnej im. gen. Józefa Bema. Obecnie teren przy ul. 29 listopada 1 zajmują koszary 10 Warszawskiego Pułku Samochodowego im. mjr. Stefana Bronisława Starzyńskiego (29 listopada 3a), klub Cavallo i (29 listopada 3b) Hotel Łazienkowski.

${ }^{57}$ Nieistniejącą obecnie ul. Bończa Niemcy przemianowali 30 VII 1943 r. na Soldatenstrasse — znajdowała się ona na mokotowskich Sielcach, obecnie jest to część zachodniego odcinka ul. Gagarina.
} 
przedpolu. Następnego dnia powstańcy na odcinku północnym ponownie wykrwawili się przy mniej intensywnych walkach — ,uwaga nieprzyjaciela jest skierowana na Wisłę, czego dowodem jest w tym kierunku skierowany ogień artylerii niemieckiej [...] na odcinku kpt. Janusza [Wyszomirskiego] — rtm. Garda jedynie słaba działalność artylerii, czołgów i broni maszynowej" - meldował komendant Rejonu V ppłk Adam Remigiusz Grocholski ps. „Waligóra”. Kolejny dzień upłynął na ostrzale przez działa szturmowe i ciężką broń piechoty, natomiast wieczorem zaatakowały bombowce Junkers Ju-87 D „Stuka”, niszcząc dwa punkty oporu, w tym kwaterę rtm. „Gardy”. Pod wpływem tych uderzeń dowódca odcinka zwrócił uwagę ppłk. „Waligórze” na przemęczenie i ciężkie straty podwładnych i „katastrofalny stan budynków bronionych". Straty powstańców w dniach 10, 12-14 września wyniosły dwudziestu ośmiu zabitych i czterdziestu ośmiu rannych. Por. „Wirski” meldował, że w jego kompanii nie było ani jednego dowódcy plutonu. Decydujący okazał się 15 września, gdy pozycje batalionu „Ryś” zostały zaatakowane z trzech stron, w tym przez Białorusinów od północy — powstańcy wycofali się na róg ul. Dolnej i Piaseczyńskiej. To wówczas ciężko ranny rtm. „Jeżycki” dobił się, a jego pluton przestał istnieć. Obrona Sielec pochłonęła 300 poległych i rannych z szeregów pułku AK „Waligóra” — gen. Rohr uzyskał swobodę działania na kierunku zarównocCzerniakowa, jak i Siekierek, zdobywając płonące w wielu miejscach Sielce ${ }^{58}$.

Jednocześnie Srebrnym Medalem 2 klasy Odznaczenia za Waleczność dla Narodów Wschodnich (Tapferkeitsauszeichnung für Angehörige der Ostvölker 2. Klasse in Silber) zostali uhonorowani Gefreiter (starszy szeregowiec) Anatol Jurewitsch (Jurewicz) oraz Unteroffizier (kapral) Peter Monitsch (Piotr Monicz), służący w Schutzmannschafts Bataillon der Sipo 13. Pierwszy z nich był łącznikiem, które ,swoje zadania wykonywał wzorowo i odważnie za dnia i w nocy, mimo intensywnego ostrzału przez strzelców wyborowych [...] Po kolejnym przeniesieniu meldunku przez niego 11. 9. 44. spotkał około godz. 19. na Dorfstraße [ul. Wiejska] grupę ze swojej kompanii, która podążała na nowe pozycje, ale kierowała się w niewłaściwą stronę, a po dalszym krótkim marszu zostaliby zaatakowani i całkiem wytraceni przez powstańców. Jurewicz przebiegł zdecydowanie w poprzek wolnej przestrzeni nie zważając na ostrzał i wyprowadził grupę z niebezpieczeństwa $\mathrm{w}$ ostatniej minucie. $\mathrm{Na}$ skutek szybkiego działania J.[urewicza] i jego odważnej interwencji została uniknięta strata całej grupy”. Tymczasem Monicz „nie mając skończonych jeszcze 20 lat, już jest dowódcą grupy [baterii] średnich moździerzy $8,2 \mathrm{~cm}$ [81 mm]. Odznaczył się nie tylko na Białorusi przy akcjach przeciw [«]Bandom[»] [w pacyfikacjach oddziałów partyzanckich], ale również tutaj jako jeden z pierwszych Białorusinów z powodu swojego męstwa podczas wkroczenia 13 batalionu [Sipo w dniu] 3. 8. 44 do Warszawy został odznaczony Tapferkeitsauszeichnung für Angehörige der Ostvölker 2. Klasse in Silber. Od tamtej pory Monicz ze swoją grupą [baterią] moździerzy jest stale w akcji, najpierw w związku kompanijnym [Kompanieverband] i później jako pojedyncza grupa [Einzelgruppe], która stale była rzucana tam, gdzie wymagało to przezwyciężania ciężkiego oporu. Monicz nigdy nie zawiódł, stale wykazywał się

\footnotetext{
${ }^{58}$ Wnioski odznaczeniowe policjantów z 13 batalionu policji pomocniczej SD podpisywał SS-Sturmbannführer Siegmund Buchberger (15 II 1906-kwiecień 1945), członek SS (nr 117.058), szef Abteilung III (SD) w KdS Warschau od stycznia 1944 do stycznia 1945 r. Od 16 XII 1944 do stycznia 1945 r. był jednocześnie KdS (Kommandeur der Sipo und des SD) Warschau. Popełnił samobójstwo pod koniec oblężenia Festung Posen (Poznań). Według drugiej wersji był widziany pod koniec lat czterdziestych XX w. w sowieckim obozie jenieckim na Syberii. Zob. AIPN, GK 107/14 (Der KdS u. Des SD für den Distrikt Warschau B. Nr. - IA - Vorschlagsliste zur Verleihung der Tapferkeitsauszeichnung für Angehörige der Ostvölker 2. Klasse in Gold - Ilja Sanetz; 2. 12. 1944), k. 41-42; A. Borkiewicz, op. cit., s. 549-557.
} 
szczególnym zacięciem, a z powodu swojej dzielności i celności wielokrotnie otrzymywał pochwały niemieckich oficerów. Dla dalszej motywacji młodego Monicza i [podległej mu] grupy proponuję odznaczyć go z powodu jego nadzwyczajnych umiejętności i dzielności"59.

Odznaczenie za rany (Verwundetenabzeichens in Schwarz) przypadło Soldatowi (szeregowiec) Michaelowi Korbutowi za walki 23 września. Podobnie odznaczeni zostali dwaj Gefreiterzy (starszy szeregowcy) Grafin Beyko i Philipp Sergenia za rany odniesione 26 września. Po zakończeniu walk w Warszawie białoruski batalion, liczący 600 policjantów, został wycofany, a poszczególne jego kompanie rozrzucono pod całej Europie ${ }^{60}$.

Na Woli, Starym Mieście i Czerniakowie walczył 1 wschodniomuzułmański pułk SS (Ostmuselmanische SS-Regiment 1) podporządkowany Angriffsgruppe Dirlewanger. Oddziałem dowodził SS-Sturmbannführer Franz Liebermann. Postępowanie żołnierzy środkowoazjatyckich przypominało standardy panujące w SS-Sonderregiment Dirlewanger, o czym wspominaliśmy wyżej. „Turkiestańczycy także walczyli po naszej stronie, podczas operacji i byli absolutnie bezwartościowi dla nas. Nawet socjalnie nieprzystosowanych z obozów koncentracyjnych czy przestępców z Wehrmachtu uważaliśmy za lepszych od nich" — wspominał anonimowy podoficer z II batalionu. Łącznie zginęło 48 szeregowców i podoficerów ,turkiestańskich”, 186 zostało rannych (w tym 9 oficerów), a siedmiu zaginęło. Łącznie przeżyło 575 ochotników środkowoazjatyckich.

Częstokroć ludność cywilna myliła Turkiestańczyków (tak Niemcy określali mieszkańców Kazachstanu, Kirgistanu, Tadżykistanu, Turkmenistanu i Uzbekistanu) z Kałmukami, którzy nie walczyli z powstańcami, gdyż nie było ich w Warszawie. Kalmückisches Kavalleriekorps (Kałmuckim Korpusem Kawalerii) dowodził Oberstleutnant Bergen vel Pipgorra. W lipcu 1944 r. Kałmucy zostali przerzuceni do dystryktu radomskiego, zajmując się zwalczaniem ruchu partyzanckiego i osłoną tamtejszego przemysłu zbrojeniowego pracującego dla III Rzeszy (Kielce, Radom, Skarżysko-Kamienna, Szydłowiec). Ochotnicy kałmuccy spacyfikowali dziesięć wsi Kielecczyzny, gdy trwał zryw powstańczy ${ }^{61}$.

W składzie wojsk zwalczających Powstanie Warszawskie były również oddziały azerskie Ostlegionen. Od pierwszych dni powstania był zaangażowany II (azerski) batalion oddziału specjalnego „Bergmann” pod dowództwem majora Huberta Mertelsmanna. W jego składzie

${ }^{59}$ AIPN, GK 107/14 (Der KdS u. Des SD für den Distrikt Warschau B. Nr. - IA - Vorschlagsliste zur Verleihung der Tapferkeitsauszeichnung für Angehörige der Ostvölker 2. Klasse in Silber - Anatol Jurewitsch, Peter Monitsch; 2 XII 1944), k. 43-44.

${ }^{60}$ Rozmieszczenie kompanii 13 batalionu SD wyglądało po październiku 1944 r. następująco: 1. - Lebrechtsdorf (Potulice — UWZ Lager Lebrechtsdorf-Potulitz?), Nichachoff (?), Berlin, 2. — Leslau (Włocławek), 3. - Triest, 6. i 7. - najpierw Zichenau (Ciechanów), a potem Neustadt (Wejherowo), Tiegenhof (Nowy Dwór Gdański). Zob. AIPN, GK 107/14 (Der KdS u. Des SD für den Distrikt Warschau B. Nr. - IA - Verleihung des Verwundetenabzeichens in Schwarz - Michael Korbut, Grafin Beyko, Philipp Sergenia [w przypadku dwóch ostatnich nazwisk doszło zapewne do omyłkowego wpisania daty 26 VI 1944]; 2 XII 1944), k. 47-47v; J. Grzybowski, op. cit., s. 318-321.

${ }^{61}$ AAN T-175, rol. 162, kl. 2694783-4; Anonim, Memoir, s. 64; Ludność cywilna, op. cit., t. I (relacja Anny Bagieńskiej), s. 204; И. Гилязов, Легион «Идель-Урал», Москва 2009, s. 184-191 (w tej ciekawej książce, poszerzającej wiedzę o Ostlegionen, nie została w ogóle wspomniana rola Ostmuselmanische SS-Regiment $1 \mathrm{w}$ pacyfikowaniu Powstania Warszawskiego); J. Gdański, Zapomniani żotnierze Hitlera, Warszawa 2005), s. 182; A. Munoz, Forgotten Legions. Obscure Combat Formations of the Waffen-SS, Boulder 1991, s. 166, 167; oraz Katmucki Korpus Kawalerii. Zbrodnie popetnione na ziemiach polskich w 1944 w dokumentach SB, red. R. Sodel, Lublin 2011, s. 31, 32; M. Lacko, P. Tesarek, 1. Východomoslimský Pulk SS na Slovensku (Október 1944-Február 1945), Trnava 2006, s. 20 [dzięki uprzejmości Arkadiusza Karbowiaka]; S. Płoski, Materiały, op. cit., s. 17. 
znajdowały się trzy kompanie azerskie $(5,6,7)$ oraz jedna północnokaukaska (8). Niemiecki por. rez. Alois Meixner z 6/Aserbeidsch.Btl. Bergmann został odznaczony 10 X 1944 r. Deutsches Kreuz in Gold. W ramach Angriffsgruppe Dirlewanger walczył I/111 batalion azerski polowy (Aserbeidschanische Feld-Bataillon I/111) „Dönmec”. Dowodził nim kapitan Werner Scharrenberg. Azerowie walczyli w składzie Kampfgruppe Reinefarth; dokładniej większość była również podporządkowana Dirlewangerowi, natomiast 7 kompania trafiła do Angriffsgruppe Reck (dowódca major Max Reck). Ci pierwsi walczyli m.in. w kompleksie cmentarzy wolskich, gdzie zostały przetrzebione 2 i 3 pluton tej kompanii — po prostu oddział wyspecjalizowany w walkach górskich był nieprzygotowany do bojów w warunkach miejskich. Dość szybko, choć bezskutecznie zaprotestował 22 VIII 1944 r. azerski Kurułtaj (Medżlis) przeciwko wykorzystywaniu azerskich żołnierzy w walce z Polakami, którzy odnosili się pozytywnie do emigrantów z Azerbejdżanu po 1918 r. Wówczas Niemcy wystosowali memorandum, wyjaśniające, ze Azerowie nie walczą z polskim narodem, ale z „komunistycznym buntem”. Wspominany Gustaw Davidhazy spotkał prawdopodobnie właśnie ich: „W czasie marszu na kwaterę posłano mnie do pewnej placówki Wehrmachtu. Po drodze musiałem przejść koło kwatery azerbejdżańskich kozaków [II/,Bergmann” lub I/111 pułku azerskiego — przyp. aut.]. Już $\mathrm{z}$ daleka słyszałem głośny, monotonny śpiew pijanych. Gdy zbliżyłem się, dostrzegłem pewną liczbę młodych dziewcząt. Kilka z nich brutalni nomadowie zapędzili do domów. Okrutny śmiech innych towarzyszył tej dziesiątce. Jeszcze długo brzmiał w mych uszach rozpaczliwy krzyk tych nieszczęsnych, zagwałconych na śmierć”. Po zakończeniu powstania resztki batalionów II/„,Bergmann” i I/111 pułku azerskiego najpierw nadzorowały ewakuację powstańców po kapitulacji. Pierwszy z nich liczył 243 żołnierzy, natomiast drugi z wymienionych 264 Azerów. Następnie zostały przetransportowane do Neuhammer (Świętoszów), a stamtąd do Husum (Hüsem) w okręgu Nordfriesland w prowincji Schleswig-Holstein ${ }^{62}$.

\section{Ukraińcy przeciw powstaniu}

Sprawa udziału Ukraińców w tłumieniu Powstania Warszawskiego wzbudza wiele kontrowersji i emocji. W Polsce jest rozpowszechniona opinia, że pododdziały 14 Galicyjskiej Ochotniczej Dywizji SS (14 Galizische SS-Freiwilligen-Division) dowodzonej przez SSBrigadeführera Fritza Freitaga były odpowiedzialne za liczne masowe mordy na ludności stolicy $^{63}$. Ukraińcom zostały przypisane zbrodnie innych, ponieważ Polacy — pod wpływem

\footnotetext{
${ }^{62}$ Oba bataliony przybyły walczyć z powstańcami w pełni sił i kompletnie wyposażone, gdyż w lipcu zostały uzupełnione na poligonie Wandern koło Frankfurtu nad Odrą, gdzie szkoliły się u boku I batalionu (gruzińskiego)/ Bergmann [1, 2, 3 kompania strzelecka, 4 kompania broni zespołowej] majora Edmunda Brauna oraz III (kaukaskiego)/Bergmann [9 szwadron kawaleryjski, 10, 11 kompania strzelecka, 12 kompania broni zespołowej] majora Karla Horstmanna. Tymczasem azerski I/111 batalion został w marcu 1945 r. przeformowany w III batalion 1627 pułku grenadierów 599 Grenadier Brigade „Russland". Zob. AAN, T-78, rol. 422, kl. 6391920; Powstanie..., dok. 112 (Protokół przesłuchania żołnierza Brygady Szturmowej SS „Dirlewanger” Gustava Davidhazy’ego, 30 VI 1947), s. 724; Э. Абрамян, op. cit., s. 152-158; J. Gdański, op. cit., s. 181, 182; H. v. Krannhals, op. cit., s. 402; A. Munoz, Hitler's Eastern Legions, t. II: The Osttruppen, 1941-1945, Bayside 2003, s. 149-153; S. Płoski, Materiaty, op. cit., s. 17.

${ }^{63}$ Badania (chronologicznie) Ryszarda Torzeckiego, Andrzeja Zięby oraz Grzegorza Motyki udowodniły, że w czasie powstania nie było w Warszawie pododdziałów dywizji SS „Galizien”. Zbrodnie przypisywane Ukraińcom popełniły nie tylko oddziały wspominanego powyżej SS-Sonderregiment Dirlewanger, pułku RONA Frołowa, ale głównie jednostki niemieckiej policji i żandarmerii. Zob. G. Motyka, Dywizja SS „,Galizien” (,Hałyczyna”), „Pamięć i Sprawiedliwość” 2002, nr 1 (1), s. 116, 117; R. To-
} 
informacji zasłyszanych o pogromach dokonywanych na Wołyniu przez UPA (a w Galicji Wschodniej przez UNS) — określali jako ukraińskie wszystkie rosyjskojęzyczne, „wschodnie" oddziały cudzoziemskie, walczące po stronie III Rzeszy. Nie znaczy to jednak, że żaden Ukrainiec nie brał udziału w tłumieniu powstania. Przed „Godziną W” dwie ukraińskie kompanie wartownicze (80-150 ludzi) stacjonowały w rejonie alei Szucha i przy ulicy Wawelskiej w budynku Wyższej Szkoły Nauk Politycznych. Możliwe, że ten pierwszy oddział jest mylony z białoruskim batalionem Sipo. Czterdziestu Ukraińców było zatrudnionych też jako wartownicy na Pawiaku. Nie ma dowodów na to, aby wspomniani ukraińscy policjanci brali udział w mordach na ludności ${ }^{64}$.

Istnieją wątpliwości dotyczące Ukraińców walczących w II bataillon SS-Sonderegiment Dirlewanger. W składzie wojsk podległych von dem Bachowi do XI 1941 r. znajdowała się część mieszanego Polizei Schützen Regiment 34 (34 pułk strzelecki policji) dowodzony przez Oberstleutnanta der Schupolizei Franza Wichmanna, mający w swym składzie jeden batalion niemiecki i dwa mieszane z kadrą niemiecką (II i III) bataliony ukraińskie. Przed wybuchem powstania 34 pułk policyjny liczył 37 oficerów i 651 szeregowców oraz 982 ochotników obcokrajowców. Pułk został ściągnięty z niemieckiej 4 Armii w końcu sierpnia lub na początku września 1944 r. i przybył około 9-10 września w rejon Błonia. Wcześniej doszło do odwołania Wichmanna, którego 2 września zastąpił Major der Schupolizei Nachtwey, wcześniej dowodzący III batalionem. Ukraińcy uczestniczyli też w operacji przeciwpartyzanckiej „Sternschnuppe I” i „Sternschnuppe II”. Przed odtransportowaniem I/ 34 pułku strzeleckiego policji oddział przeprowadzał w ścisłej współpracy z komendantem twierdzy wielką październikową obławę na terenie ewakuowanej Warszawy w celu całkowitej ewakuacji miasta $^{65}$. Pułk liczył 1 X 1944 r.: I batalion — 290, II batalion — 404 i III batalion — 455 policjantów, w tym 533 Ukraińców

rzecki, Polacy i Ukraińcy. Sprawa ukraińska w czasie II wojny światowej na terenie II Rzeczypospolitej, Warszawa 1993, s. 253, 254; A. Zięba, Ukraińcy i Powstanie Warszawskie, „Znak” 1989, nr 413-415; B. Lewyćkyj, Ukraińcy a likwidacja Powstania Warszawskiego, „Kultura” 1952, nr 6 (56), s. 74-87.

${ }^{64}$ Podchorążowie z 14 Dywizji Grenadierów SS „Galizien” - szkoleni w ramach XVI Wojennego Kursu Podchorążych w szkole oficerskiej w Owińskach (SS-Junkerschule Braunschweig-Posen-Treskau) - sformowali kompanię grenadierów, ale najprawdopodobniej część z nich dołączyła do Kampfgruppe Reinefarth, służąc tam za tłumaczy. Natomiast z całą pewnością około tysiąca Ukraińców z Dywizji SS „Galizien” trafiło czasowo po 10 IX 1944 r. z Neuhammer jako uzupełnienie do IV SS-Panzer Korps, broniącego przedmościa modlińskiego. Walczyli do 3 XI 1944 r., a potem zostali odesłani do macierzystej jednostki na Słowacji. Zob. Ludność cywilna, op. cit., t. II (meldunek „,Laszcza” — gen. Albin Skroczyński), przypisy, s. 45-47; B. Kiekenap, Szkoła podchorązych SS w Brunszwiku z siedziba w podpoznańskich Owińskach, Poznań 2012, s. 100-102; K. Leszczyński, Heinz Reinefarth, Warszawa-Poznań 1961, s. 56-58; M. O. Logusz, Galicia Division: The Waffen-SS 14th Grenadier Division 1943-1945, Altglen 1997, s. 274, 284-289, 492-494 (przyp. 6); B. Lewyćkyj, op. cit., s. 74-87; M. Majewski, Przyczynek do wojennych dziejów Ukraińskiego Legionu Samoobrony (1943-1945), „Pamięć i Sprawiedliwość" 2005, nr 4, s. 319-321; G. Motyka, Prawda i mity o udziale Ukraińców w zwalczaniu Powstania Warszawskiego, „Powstanie Warszawskie. Fakty i mity”, Warszawa 2006, s. 118-120; S. Płoski, Materiały, op. cit., s. 50 (mówi o kompaniach Sipo i Schupo; A. S. Kowalczyk, B. Kerski, Wiek ukraińsko-polski. Rozmowy z Bohdanem Osadczukiem, Lublin 2001, s. 108, 109; Я. Овад, Бо Війна Війною..., Позен-Трескау: „Юнкершуле Брауншвайл”, w: http://lib.galiciadivision.com/ovad/ r05.html [dostęp: 23 IV 2013].

${ }^{65}$ Działania i skład narodowościowy 34 pułku policji w ramach niemieckiej 9 Armii wymagają dalszych poszukiwań w archiwach niemieckich. II batalion liczył w 1943 r. 253 ludzi, natomiast III batalion 280. Borkiewicz sygnalizuje, że II i III/Polizei Schützen Regiment 34 były podległe Dirlewangerowi od trzeciej dekady września. Zob. AAN, T-175, rol. 8, kl. 2509158 (dane z 1943 r.); T-311, rol. 218, kl. 475 
W działaniach w stolicy brało też udział czterystu policjantów z Ukraińskiego Legionu Samoobrony - ULS (Український Легіон Самооборони -УЛС), znanego też jako Schützmannschaft Bataillon der Sipo Nr. 31, pod dowództwem pułkownika Petra Diaczenki. ULS znalazł się w Warszawie w pierwszych dniach września ${ }^{66}$. Nadal problem stwarza ustalenie rejonu koncentracji i dokładnego miejsca walk ULS w Warszawie. Relacje świadków sugerują rozmieszczenie Ukraińców w rejonie ul. 6 Sierpnia (obecnie aleja Wyzwolenia/Nowowiejska) lub przy ul. Rozbrat podczas niemieckiego szturmu na Powiśle. Według danych niemieckich w walkach na Powiślu zginęło dziesięciu legionistów, natomiast trzydziestu czterech zostało rannych. 13 września rozpoczęło się niemieckie natarcie na Czerniaków Górny. W tych walkach ULS mógł obsadzać do 23 września pozycje znajdujące się pomiędzy obecnym parkiem im. Rydza-Śmigłego a Wisłą. Natarcia były prowadzone w kierunku ul. Wilanowskiej i Ludnej. Ukraińcy mogli okopać się na Wybrzeżu Kościuszkowskim, a później zajęli pozycje na wschód od ul. Frascati. Przeciwnikami ULS byli żołnierze z pozostałości oddziału dyspozycyjnego Kedywu OW AK „Kolegium A” pod dowództwem por. Bolesława Góreckiego ps. „Snica” (wchodzącego w skład kompanii batalionu „Zośka”) ze zgrupowania „Radosław” oraz „berlingowcy". To wówczas ukraińscy legioniści ponieśli najcięższe straty.

Później ULS przerzucono na skraj Puszczy Kampinoskiej w rejonie Leszna, gdzie wraz ze wspomnianym 34 pułkiem strzeleckim policji dozorował przedpole Warszawy ${ }^{67}$. Grupa Diaczenki uczestniczyła w pościgach za partyzantką. ULS dokonał 24 września pacyfikacji wsi Zaborówek w odwecie za akcję AK przeciwko niemieckim oddziałom w Puszczy Kampinoskiej. A trzy dni później rozpoczęły się trwające do 1 października operacje „Sternschnuppe I” i „Sternschnuppe II”, których celem, m. in. dla ULS, była likwidacja Grupy „Kampinos” Armii Krajowej. Te działania zakończyły się prawie całkowitą zagładą osaczonego oddziału partyzanckiego pod Jaktorowem (Budami Zosinymi) ${ }^{68}$.

\section{Zapomniani Hiwisi}

Praktycznie każda wielka jednostka niemiecka trzech rodzajów wojsk, ale też Waffen-SS, miała przynajmniej od 1943 r. na swoim stanie Hilfswiligen („ochotników pomocniczych”). Jak wiadomo, największy udział procentowy i liczbowy wśród wschodnioeuropejskich ochotników cudzoziemskich w Heer stanowili Rosjanie, których w jednostkach niemieckich służyło 300 tys., natomiast zaraz po nich na drugim miejscu plasowali się Ukraińcy (220 tys.). Kolejni pod względem liczebności byli jeńcy zamieszkujący przed 1941 r. sowieckie re-

(dane z 1944 r.); A. Borkiewicz, op. cit., s. 597; J. Gdański, op. cit., s. 221; H. v. Krannhals, op. cit., s. 415; The German Police, red. A. Munoz, Bayside 1997, s. M22-23; S. Płoski, Materiaty, op. cit., s. 16, 17.

${ }^{66} \mathrm{Na}$ pewno przed 4 września, co wynika z pisma SS-Oberscharführera Gustava Raulinga z 12 X 1944 r. informującego o stratach ULS w Warszawie. Zob. M. Majewski, op. cit., s. 318.

${ }^{67}$ Rejon walk na Powiślu legion opuścił po około dwóch, maksimum trzech tygodniach, na pewno po 13 września — to również wiadomo z pisma Raulinga - ale niewykluczone, że dopiero w momencie upadku Czerniakowa, tj. 23 września. Już następnego dnia legion działał w Puszczy Kampinoskiej, co odnotowują dokumenty niemieckie, $\mathrm{m}$. in. pismo SS-Oberscharführera Raulinga dotyczące strat legionu podczas walk w Warszawie (Einsatz in Warschau) z 12 X 1944 r. Zob. J. Kirchmayer, op. cit., zał. nr 34, s. 553; M. Majewski, op. cit., s. 318.

${ }^{68}$ Grupa bojowa ULS Diaczenki miała liczyła według danych niemieckich 219 żołnierzy. Zob. J. Kirchmayer, op. cit., zał. 34, s. 553; B. Lewyćkyj, op. cit., s. 85 (według autora były to dwie sotnie (kompanie) liczące czterystu ludzi); M. Majewski, op. cit., s. 318 (za: AP Kraków, 426, d. Biblioteka Jagiellońska, Dz. Rkp., Verzeichnis der in Warschau befindlichen Angehoerigen des SMdS-Batl 31, k. 125-131); R. Torzecki, op. cit.; s. 253; J. Krzyżanowski, op. cit., s. 529. 
publiki środkowoazjatyckie - było to 180 tys. Turkiestańczyków (jak Niemcy „zbiorczo” określali Kazachów, Kirgizów, Tadżyków i Uzbeków). Do 1943 r. każda niemiecka dywizja piechoty posiadała etatowo 700 Hiwisów, wspierających wysiłek niemieckich Übermeschen przez wyręczanie ich w aprowizacji i logistyce oddziałów frontowych na każdym szczeblu. OKH rozszerzyła w październiku tego roku zakres służby Hiwisów na dywizyjnych tyłach, zwiększając etat do najwyższego stanu 2005 „ochotników pomocniczych”. Podobnie było w dywizjach piechoty wzoru 1944, gdzie służyło 1454 Hiwi, rekrutujących się z jeńców sowieckich i pochodzących $\mathrm{z}$ ochotniczego zaciągu obywateli terytoriów okupowanych ZSRS. Tymczasem w wehrmachtowskich dywizjach pancernych wz. 1944 znajdowało się 714 Hiwi, co oznaczało zmniejszenie ich liczebności do etatów z 1943 r. o 256 „ochotników pomocniczych”. Łącznie w lipcu 1944 r. w czterech grupach armii na froncie wschodnim 205 tys. wschodnioeuropejskich ochotników cudzoziemskich, w tym 186 tys. Hiwisów.

W efekcie po podliczeniu etatowych stanów jednostek 9 Armii oraz Korpsgruppe von dem Bach, zaangażowanych w pacyfikację Powstania Warszawskiego, po uśrednieniu dochodzi jeszcze 8 tys. -9 tys. Hiwi. Wschodnioeuropejscy ochotnicy cudzoziemscy wchodzili w skład następujących „wielkich jednostek” Ostheer walczących lub stacjonujących w rejonie Warszawy od sierpnia do października 1944 r.: 3 i 5 Dywizja Pancerna SS, 19 i 25 Dywizja Pancerna, Dywizja Strzelecko-Spadochronowo-Pancerna „Hermann Göring”, 73 Dywizja Piechoty, Dywizja Forteczna „Warschau”, 1131 Brygada Grenadierów. Ale pamiętać należy, że nawet etaty niemieckich oddziałów zabezpieczenia przewidywały wykorzystanie Hiwi (przykładowo Sicherungs-Bataillon 638 i 258 czy wspomniany Sicherungs-Regiment 57 odpowiednio $21-58-213$ Hiwi). Oczywiście wspomniane oddziały i jednostki zmieniały swą dyslokację, natomiast przez Warszawę przewijali się Hiwisi ze służb tyłowych różnych jednostek i oddziałów, chociażby stykając z Polakami na zapleczach obszarów tyłowych podczas zadań aprowizacyjnych ${ }^{69}$.

Tragiczne losy Powstania Warszawskiego odcisnęły się na najnowszej historii Polski. Dlatego tak ważne jest, aby ta krwawa karta dziejów wojennych została oczyszczona z niedomówień. Jedynie zasada obiektywnej bezstronności pozwoli przedstawić dzieje jednego z największych polskich zrywów powstańczych w sposób zgodny z prawdą historyczną.

${ }^{69}$ Przykładowo odtwarzana po walkach pod Kamieńcem Podolskim 25 Dywizja Pancerna posłużyła do utworzenia jednej z Heeres Panzer Brigaden. Natomiast już 5 sierpnia przyszły nowe rozkazy, nakazujące sformowania Kampfgruppe 25 Panzerdivision, która została skierowana we wrześniu do Warszawy na przeszkolenie i zgranie oddziałów z udziałem broni ostrej. Zob. AAN, T-78, rol. 398, k1. 6367802 (OKH/Gen.St.d.H./Org.Abt.Nr.16900/44, Grundliederung der Inf.Div.44 mit stärkeberechnung Personelle Stärkeberechnung einer Inf.Div.44, Seite 3, 15 VII 1944) [1.454 Hiwi]; T-78, rol. 410, kl. 6378497 (Grundliederung Panzer-Division 43, bd); kl. 6378491 (Grundliederung Panzer-Division 44, 22 VII 44); kl. 6378492 (Grundliederung 3. SS-Panzer-Division „,Totenkopf”, 22 VII 44); k1. 6378597 (OKH/Gen.Insp.d.Pz.Tr./GenStdH/Org.Abt./Kartei Nr 2500/44, Grundliederung Panz. Div.44 mit stärkeberechnung Personelle Stärkeberechnung einer Panz.Div.44, Anlage 3, 15 VIII 1944) [714 Hiwi]; kl. 6378619 (Heerespersonalamt 1./Staffel/Chefgr, Stärken der Divisionen, Anlage 10, Stärkeberechnung einer Pz.Div. 43, bd) [970 Hiwi - etat DPanc wz. 43 obowiązywał do 3 VIII 1944]; T-78, rol. 411, kl. 6379558 (Mustergliederungen von Div.-Verbänden - Gliederung einer SS-Pz.Div, 24 VII 44); kl. 6379616 (Org.Abt.(I),Nr.I/8561/44, Bestand en etatisierten ostvölkischen innerhalb des Ostheeres and Bedarf an Hiwi im Bereich der H.Gr. D und C, Stand 1.7.44; 7. 08. 1944); T-175, rol. 111, kl. 2635940 (Stärkemeldung der SS am 30 VI 1944); T-354, rol. 639, kl. 010 (Stärkemeldung der 5.SS-Pz.Div. ,,Wiking” von 4. 03. 1944).Th. L. Jenz, Panzertruppen. The Complete Guide to the Creation \& Combat Employment of Germany's Tank Force 1943-1945, Atglen, 1996, s. 158-160; G. Tessin, op. cit., Band 04, Die Landstreitkräfte 15-30, Frankfurt am Main 1970, s. 226-228. 
Przede wszystkim chodzi o naprawienie pokutującego od ponad sześćdziesięciu lat lat mitu buddyjskich Kałmuków, „Mongołów”, „ukraińskich zwyrodnialców” z SS-Galizien i „własowców" mordujących Polaków w czasie Powstania Warszawskiego. Nawet ostatnio pojawiły się dezinformacje o Kozakach, ściąganych do Warszawy z dalekich Włoch, czy Dywizji Pancernej SS „Hermann Göring” [sic! wg oficjalnej nomenklatury ,,strzelecko-spadochronowo-pancernej” — Fallschirm-Panzer-Division „Hermann Göring”] posiadającej na wyposażeniu czołgi ciężkie Pz. Kpfw. VI Ausf. E. „Tiger I”. Tych Reichsmarschall nie pozyskał od Speera, ale zdobył jesienią 1944 r. dla swoich podwładnych równie znakomite czołgi średnie Pz. Kpfw. V „Panther”. Jednak w Warszawie czołgiści Göringa walczyli jeszcze na starszych czołgach średnich Pz. Kpfw. IV w ramach II/ Fs.Pz.Rgt „HG” oraz niszczycielach czołgów Panzerjäger IV/48, Sd. Kfz. 162 Jagdpanzer IV/48 z III/ Fs.Pz.Rgt „HG”.

A czołgów „Tiger I” było w Warszawie kilka i niczym szczególnym się nie wyróżniły, ale ich wszechobecność w relacjach mogła być skutkiem popularności słów wojennego hymnu batalionu harcerskiego AK „Parasol” Pałacyk Michla autorstwa Józefa Szczepańskiego ps. „Ziutek” („Choć na «tygrysy» mają visy, To warszawiaki, fajne chłopaki są”). Faktycznie zaś było od trzech do sześciu czołgów „Tiger I” ze składu 9 (schwere) Kompanie SSPanzerregiment 3 „Deutschland”, podporządkowanych do 12, a nawet 15 sierpnia doraźnie improwizowanej kompanii pancernej SS-Panzer Grenadier Ausbildung und Ersatz Bataillon 3, sąsiadującej z warsztatami naprawczymi na terenie „Staufer-Kaserne” przy Rakowieckiej (obecnie siedziba Sztabu Generalnego przy tej ulicy). Ważny jest też obiektywny odbiór postaci gen. Andrieja Własowa oraz oddziałów autoramentu sowieckiego, współpracujących z Niemcami przy realizacji imperialnych założeń polityki III Rzeszy ${ }^{70}$.

Wschodnioeuropejscy ochotnicy cudzoziemscy angażowali się zarówno do lokalnych eksterminacji, jak i nieoczekiwanego czy może wyrachowanego uratowania powstania praskiego w maju 1945 r. Podstawowe uwarunkowanie warsztatowe sine ira et studio wymaga opisywania działań strony niemieckiej, pacyfikującej Powstanie Warszawskie, w oparciu o jak najszerszą kwerendę dokumentów wytworzonych przez III Rzeszę w niemieckim Bundesarchiv-Militärarchiv. Pamiętając, że najgorsze zbrodnie na ludności cywilnej pozostaną terra incognita dla badaczy z braku chęci weteranów niemieckiej policji, SS i Wehrmachtu do szczerych wyznań, czy nawet niepodjęcia prób zapytania ich o to, co faktycznie rozgrywało się na ulicach Warszawy.

\section{East European Foreign Volunteers in German Ostheer, SS, and Police Divisions Pacifying the Warsaw Uprising. The Case of the "Vlasovites", Kalmuks, and SS Galizien...}

The intention of this article is to bring the reader closer to a little-known aspect of foreign forces used by the Germans in the pacification of the Warsaw Uprising. The author was especially interested in tackling myths concerning the participation of Kalmuks, the Ukrainians serving in the 14th Waffen Grenadier Division of the SS, and the so-called Vlasovites in battles waged against the insurgents.

The article describes the emergence of foundations serving a myth about the part played by the above-listed nationalities in combatting the Warsaw Uprising. The Germans deployed all available police, SS, and Wehrmacht forces to eliminate danger in the direct war front hinterland of the 9th Army. Nonetheless, Wehrmacht commanders did not take over divisions fighting

\footnotetext{
${ }^{70}$ AAN, T-78, rol. 411, k1. 6379532-6379552, szcz. k1. 6379550-6379551 (OKH, GenStdH/Org.Abt. (I), Br. I/18310/44, Mustergliederung von Div.-Verbänden, Stand Juli 1944; 24 VII 1944); T. L. Jenz, op. cit., s. 153, 206.
} 
in Warsaw. This standstill in the command structures was exploited by Himmler, who appointed SS-Obergruppenführer und General der Waffen-SS und der Polizei Erich von dem Bach as commander. The article discusses the engagement of the "hiwi", "osttruppen", and "ostlegionen" mosaic deployed by the Germans during the pacification of the Warsaw Uprising and composed of Russians, Byelorussians, Ukrainians, Cossacks, Turkmens, Azeris, etc. The reason for this state of things was the lack of sufficient forces, although ultimately the resistance of the insurgents was crushed by German panzer divisions. From the very beginning a foremost role in slaying the inhabitants of Warsaw was played by the Germans (police, gendarmerie, and the SS), responsible for the deaths of many more victims than those killed by former Soviet citizens, despite all post-war attempts at transferring the guilt to divisions collaborating with the Third Reich. Stifling the Warsaw Uprising (and the Slovak National Uprising) proved to be the apogee of the German anti-partisan campaign, part of the bloody Bandenbekämpfung tactic. 